OECD Economics Department Working Papers No. 1121

Local Public Finances and Municipal Reform in Finland

Christophe André, Clara García 
Organisation de Coopération et de Développement Économiques

Organisation for Economic Co-operation and Development

03-Jun-2014

ECONOMICS DEPARTMENT

English - Or. English

LOCAL PUBLIC FINANCES AND MUNICIPAL REFORM IN FINLAND

ECONOMICS DEPARTMENT WORKING PAPERS No. 1121

By Christophe André and Clara García

OECD Working Papers should not be reported as representing the official views of the OECD or of its member countries. The opinions expressed and arguments employed are those of the author(s).

Authorised for publication by Alvaro Pereira, Director, Country Studies Branch, Economics Department.

All Economics Department Working Papers are available through OECD's Internet website at http://www.oecd.org/eco/workingpapers

JT03358601

Complete document available on OLIS in its original format

This document and any map included herein are without prejudice to the status of or sovereignty over any territory, to the delimitation of international frontiers and boundaries and to the name of any territory, city or area. 
OECD Working Papers should not be reported as representing the official views of the OECD or of its member countries. The opinions expressed and arguments employed are those of the author(s).

Working Papers describe preliminary results or research in progress by the author(s) and are published to stimulate discussion on a broad range of issues on which the OECD works.

Comments on Working Papers are welcomed, and may be sent to the Economics Department, OECD, 2 rue André-Pascal, 75775 Paris Cedex 16, France, or by e-mail to econ.contact@oecd;org.

This document and any map included herein are without prejudice to the status of or sovereignty over any territory, to the delimitation of international frontiers and boundaries and to the name of any territory, city or area.

The statistical data for Israel are supplied by and under the responsibility of the relevant Israeli authorities. The use of such data by the OECD is without prejudice to the status of the Golan Heights, East Jerusalem and Israeli settlements in the West Bank under the terms of international law. 
ECO/WKP(2014)17

\section{ABSTRACT/RÉSUMÉ \\ Local public finances and municipal reform in Finland}

Finnish municipalities enjoy ample fiscal autonomy and provide or arrange the provision of a large share of public services. In recent years, their spending and debt has been increasing steadily, especially because of population ageing and increases in the cost of health care and social services. Furthermore, small municipalities are often struggling to align service provision with national standards. The government has launched a reform to create more efficient municipalities through voluntary mergers. Both international experience and costs per capita across Finnish municipalities suggest an optimal size for municipalities of over 20000 inhabitants, at least outside remote areas. As mergers are to be voluntary, the outcome of the reform remains uncertain. If merger plans prove insufficient to achieve efficient public service provision, the government could impose mergers on smaller municipalities, especially around the main urban areas. Responsibilities of smaller municipalities could be scaled back in all functions where economies of scale and scope can be achieved. Policies also need to be flexible enough to allow restructuring of services after mergers. Partnerships between public or private entities to provide services could be developed further in some areas. Finally, the tax structure and fiscal rules should be enhanced to ensure long-term fiscal sustainability.

This Working Paper relates to the 2014 OECD Economic Survey of Finland (www.oecd.org/eco/surveys/economicsurvey-finland.htm).

JEL Classification: H11, H21, H41, H42, H71, H72, H74, H75, H77

Keywords: Fiscal federalism, Local government, Decentralisation, Efficiency, Fiscal rules, Local taxation, Fiscal equalisation, Municipal mergers, Public services, Finland.

$* * * * * * * * * * * * * * * * * * * * * * * * * * *$

\section{Les finances publiques locales et la réforme des communes en Finlande}

Les communes finlandaises jouissent d'une grande autonomie budgétaire et fournissent elles-mêmes, ou font fournir, une large part des services publics. Ces dernières années, leurs dépenses et leur endettement ont augmenté de manière sensible, en particulier à cause du vieillissement de la population et de la hausse des soins de santé et des services sociaux qui en découle. En outre, les petites communes ont souvent du mal à fournir des services à la hauteur des normes nationales. Le gouvernement a lancé une réforme destiné à créer des communes plus efficientes grâce à des fusions volontaires. Si l'on se fonde sur l'expérience internationale comme sur les coûts par habitant dans les communes finlandaises, il apparait que pour une commune, la taille optimale correspondrait à une population supérieure à 20000 habitants, au moins en dehors des zones isolées. Comme les fusions vont être volontaires, l'issue de la réforme reste incertaine. Si les projets de réformes ne suffisent pas à déboucher sur une prestation efficiente de services publics, le gouvernement pourrait imposer des fusions aux communes les plus petites, en particulier autour des grandes zones urbaines. Les responsabilités des communes les plus petites pourraient être réduites dans tous les domaines où il est possible d'obtenir des économies d'échelle et de portée. L'action publique doit par ailleurs être suffisamment souple pour permettre une restructuration des services après les fusions. Des partenariats entre entités publiques et privées pour la fourniture de services pourraient être développés dans certains domaines. Enfin, la structure fiscale et les règles budgétaires devraient être améliorées pour garantir la viabilité budgétaire à long terme.

Ce Document de travail se rapporte à l'Étude économique de l'OCDE de la Finlande, 2014 (www.oecd.org/fr/eco/etudes/etude-economique-finlande.htm).

Classification JEL: H11, H21, H41, H42, H71, H72, H74, H75, H77

Mots clés : Fédéralisme budgétaire, Gouvernement local, Décentralisation, Efficacité, Règles budgétaires, Fiscalité locale, Péréquation, Fusions municipales, Services publics, Finlande. 


\section{TABLE OF CONTENTS}

LOCAL PUBLIC FINANCES AND MUNICIPAL REFORM IN FINLAND .......................................... 6

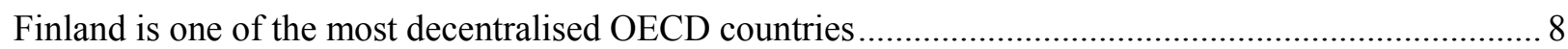

The share of local government in public revenue and spending is high ........................................... 8

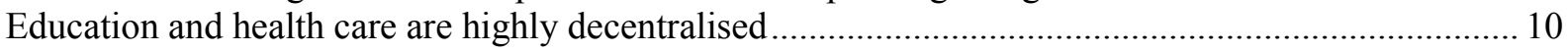

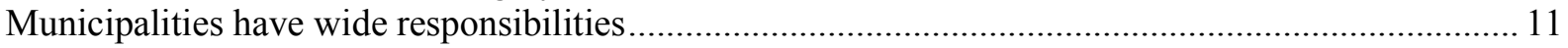

Municipalities tend to be small relative to the extent of their responsibilities .................................... 13

Local finances are deteriorating and public services becoming increasingly uneven .............................. 15

The aggregate local government deficit and debt are rising ............................................................ 15

Differences in the financial situation of municipalities are widening ................................................. 17

Ensuring equal access to services across the country is challenging.................................................. 19

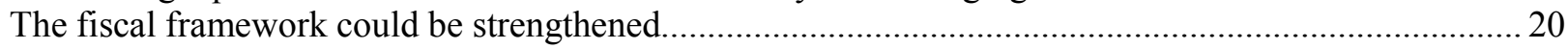

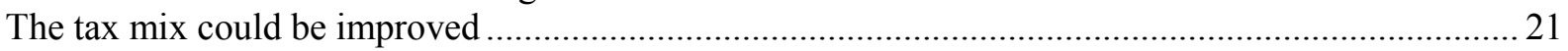

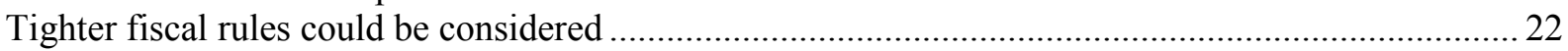

The reform of municipalities has the potential to generate efficiency gains in public services ................ 23

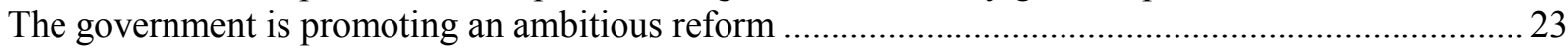

Evidence from OECD countries points to potential benefits of merging small municipalities ............. 23

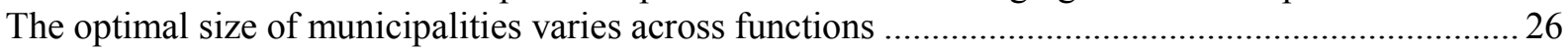

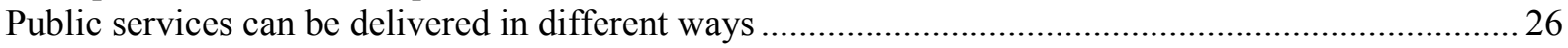

Larger municipalities would make for greater equity in access to services.......................................... 30

Reorganisation of services to achieve efficiency gains .................................................................. 30

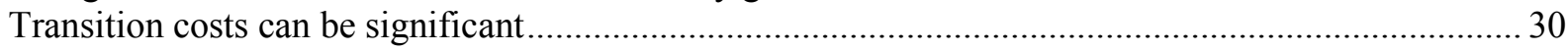

Municipal consolidation requires overcoming difficult political obstacles ......................................... 31

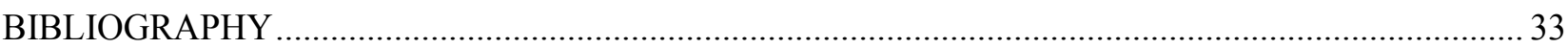

\section{Tables}

1. Sub-central government fiscal rules indicator in selected countries ............................................ 23

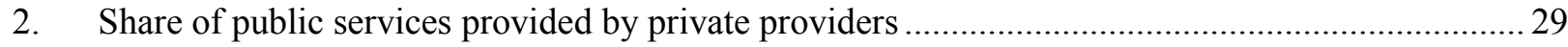

\section{Figures}

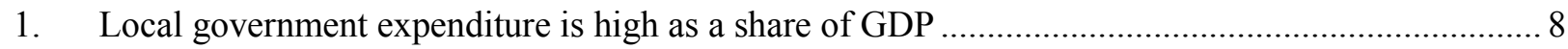

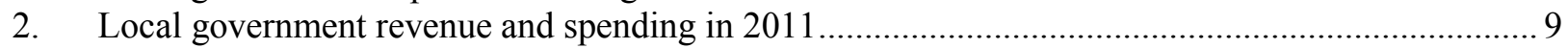

3. Local government consumption and investment................................................................... 10

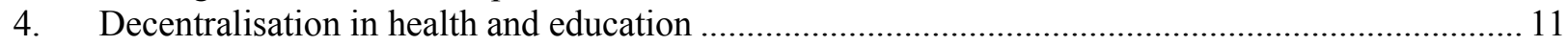

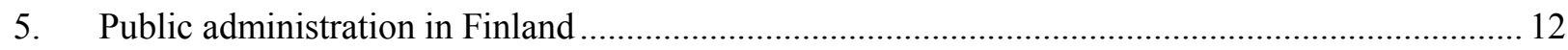

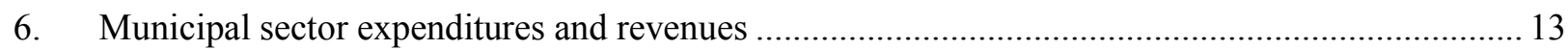

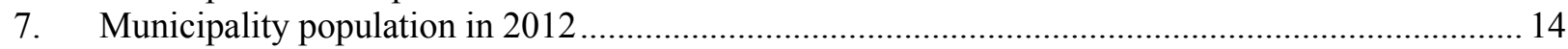

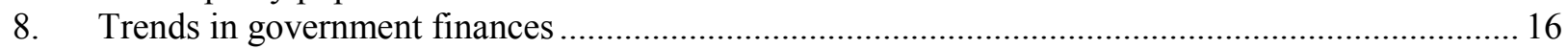

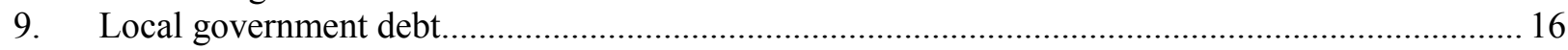

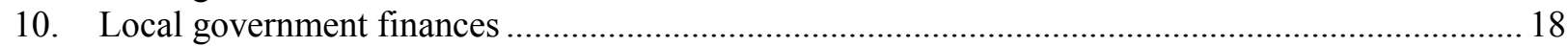

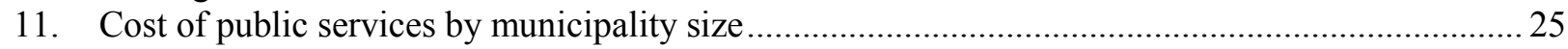

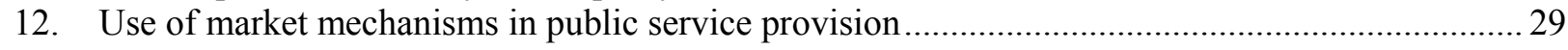




\section{Boxes}

Box 1. Ongoing reforms affecting local government...........................................................................

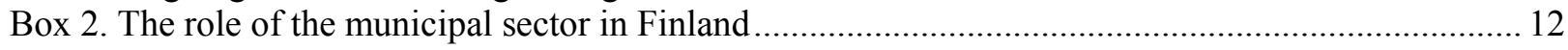

Box 3. The municipality of Salo: adjusting to the closure of the Nokia plant ....................................... 19

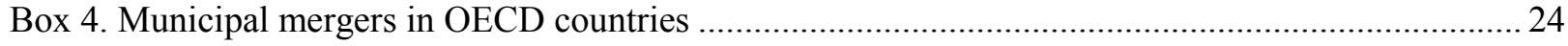

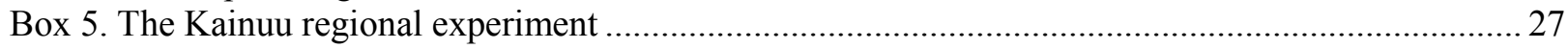




\title{
LOCAL PUBLIC FINANCES AND MUNICIPAL REFORM IN FINLAND
}

\author{
Christophe André and Clara García ${ }^{1}$
}

Finland has relatively strong public finances and is one of the few euro area countries which did not breach the Maastricht deficit ceiling of 3\% of GDP in recent years, despite fiscal stimulus in 2009-10. Sound fiscal policy allows funding quality public services. Education is consistently ranked among the best in the OECD, the health care system offers universal coverage for a wide range of high quality services, and the country enjoys good infrastructures and an extensive social safety net.

As the level of taxation is one of the highest in the OECD, the scope for increasing tax revenue is limited. While central government spending has been held in check in recent years, spending by municipalities has risen considerably. This reflects to some extent the nature of municipal spending, half of which relates to health care and social services, where demand is strong and costs are difficult to control. Municipalities are small on average, their responsibilities are vast and the possibilities for economies of scale and scope are limited. Furthermore, as population ageing pushes up demand for services and internal migration towards cities erodes the tax base of rural municipalities and reduces labour resources, small municipalities are increasingly struggling to deliver high-quality services at affordable cost.

The government has launched a number of reforms that have important implications for the functioning and financing of the local government sector (Box 1). Municipal councils have an obligation to provide merger proposals by July 2014. Consolidation could be imposed at a later stage in some areas if the government considers municipal mergers plans as insufficient. Initial reactions suggest that the number of mergers may not be sufficient to create the robust municipalities the government was hoping for. If so, mergers could be imposed on municipalities failing to reach critical size, as was done in Denmark. Alternatively, adjusting the tasks devolved to smaller municipalities to better align them with financial and organisational capacities could be considered, even though the provision of major services often has already been widely outsourced. Enlarging municipal and other joint service providers could be of greater benefit. A step in the latter direction has in fact been taken with the working group of civil servants established by the Ministry of Social Affairs and Health, which sets minimum inhabitant numbers for municipalities to retain control over health care and social service provision. New ways of delivering public services, including enhanced cooperation between municipalities and commissioning of services from external providers could also reconcile small size with efficient provision of high-quality services.

1. The authors are from the OECD Economics Department. This paper was originally produced for the 2014 OECD Economic Survey of Finland published in February 2014 under the authority of the Economic and Development Review Committee (EDRC) of the OECD. The authors would like to thank Rudiger Ahrend, Hansjörg Blöchliger, Isabelle Chatry, Andrew Dean, Robert Ford, Claudia Hulbert, Vincent Koen and other OECD colleagues, as well as officials from the Finnish government and the Government Institute for Economic Research (VATT), for valuable discussions and comments on earlier drafts. Special thanks to Nadine Dufour and Mikel Iñarritu for excellent technical preparation. 


\section{Box 1. Ongoing reforms affecting local government}

The government is pushing forward a number of reforms that will impact the local government sector. This box provides an overview of the most important ones.

\section{Voluntary mergers}

Finland has a long history of voluntary mergers, which already reduced the number of municipalities from 560 in 1945 to 416 in 2005. In that year, the government launched a project to restructure local government and services with a view to reinforce the capacity of municipalities to deliver services, through mergers and enhanced cooperation. Since then, significant municipal consolidation has taken place, reducing the number of municipalities to 320 , and intermunicipal cooperation for providing services has increased. Nevertheless, only modest results in terms of improvement in service provision seem to have been achieved (Moisio et al., 2010; Kröger, 2011). The government elected in 2011 launched a more ambitious reform to restructure municipalities and services, building on economically robust municipalities, which would enable improvements in administrative structures, productivity and effectiveness (Prime Minister's Office, 2011). Municipalities will submit mergers plans by July 2014, but it is unlikely that the number of mergers proposed will match initial expectations.

\section{Plan to impose mergers around the main urban areas}

As the government estimates benefits of mergers to be highest around main regional centres, it plans to propose a bill to parliament, which would allow forcing municipalities in about 10 urban areas to merge with the relevant regional centre.

\section{Metropolitan council of Helsinki}

The government aims at improving cooperation in the Helsinki metropolitan area to enhance services, land use, transport and communications networks, and business opportunities (Prime Minister's Office, 2011). The current plan aims at establishing an elected metropolitan council with fairly strong decision-making powers.

\section{Social and health care reform}

Plans are being devised to reduce fragmentation, improve user choice and further promote prevention. A working group set up by the Ministry of Social Affairs and Health proposes a minimum of 20000 inhabitants for municipalities to retain control over primary health care and of 50000 to organise specialised care.

\section{Steering system for local government}

A new steering system for local government finances will be put in place, with the aim of ensuring that in the future municipalities' responsibilities match the available funding. If municipalities are given new responsibilities, either existing ones are to be cut or more funding is to be provided.

\section{Fiscal rules for municipalities}

Fiscal rules will be tightened. Municipalities are currently required to balance their budget over a four-year period. However, enforcement rules are not very stringent, as correction may be spread out over several years. Going forward, such postponement of consolidation will no longer be allowed. This could lead to more municipal mergers through the compulsory adjustment procedure. 
While insufficient scale is an obstacle to efficient provision of services in some areas, size in itself does not guarantee efficiency. Past municipal mergers in Finland seem to have resulted in limited productivity gains and international evidence on the efficiency impact of mergers is mixed. It is therefore necessary to ensure that the merged municipalities take advantage of potential productivity gains through reorganisation. There are, however, some trade-offs between efficiency gains and political economy issues. In particular, the commitment to protect municipal jobs during five years after mergers may be necessary to ensure support for mergers, but could delay the necessary restructuring of services. Transition costs also need to be taken into account to ensure a smooth adjustment process.

This paper is organised as follows: the first section briefly describes the organisation of the Finnish government sector; the second documents developments in municipal finances since the mid-1990s and looks at challenges to ensuring equal access to public services across the country; the third examines how the fiscal framework could be strengthened; and the final section assesses the difficulties and opportunities offered by municipal mergers in the light of international experience.

\section{Finland is one of the most decentralised OECD countries}

Self-government is a core value, enshrined in the Constitution of Finland and translates into a high degree of decentralisation. The latter is evidenced by the large share of local government in public spending (Figure 1). This is an imperfect indicator of the autonomy of local governments, however, as national mandates and constraints on local authorities vary widely across countries. Nevertheless, institutional indicators of decentralisation constructed by the OECD for the two main areas of public service provision, education and health care, confirm the high degree of local autonomy in Finland.

Figure 1. Local government expenditure is high as a share of GDP ${ }^{1}$

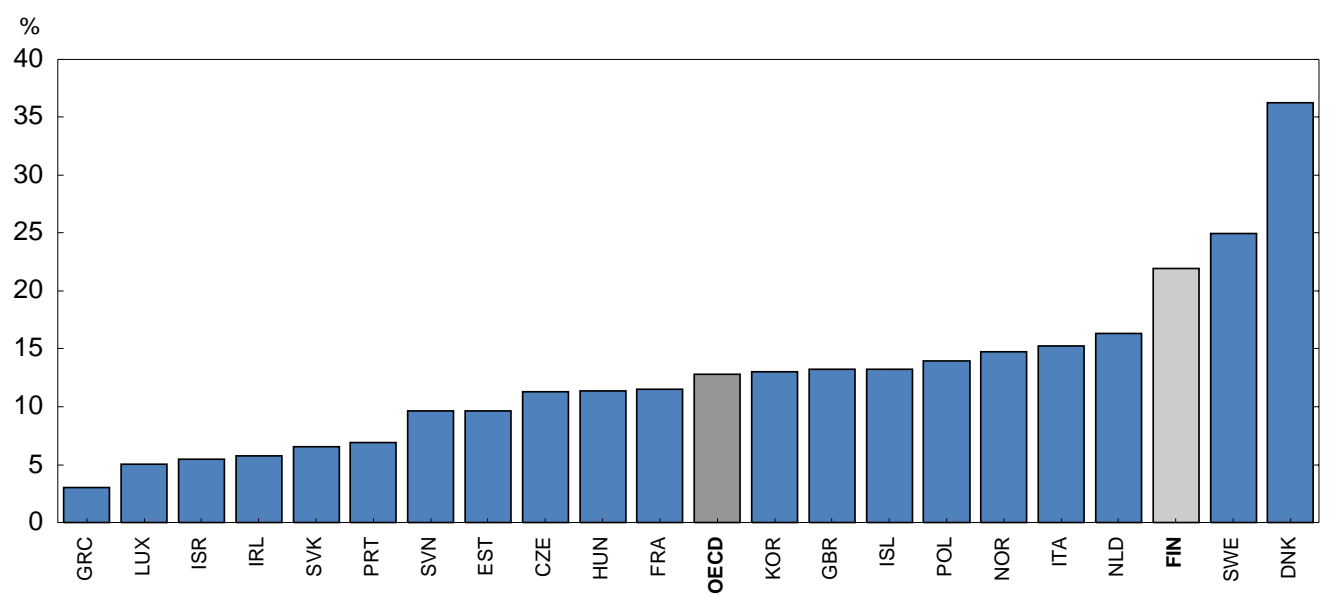

1. In 2011. Includes unitary countries only. Data for the OECD refer to an unweighted average.

Source: OECD Fiscal Decentralisation database.

\section{The share of local government in public revenue and spending is high}

Nordic countries - except Norway - stand out for having by far the largest share of government revenue collected by local authorities in the OECD. As Finland is a unitary country, the focus is on local government, rather than sub-national government, which also includes intermediate levels, especially in federal states (e.g. states or provinces). The local government share of revenue exceeds a third in Sweden and is close to $30 \%$ in Denmark, Finland and Iceland (Figure 2, panel A). The OECD average is less than 
$15 \%$ and the first non-Nordic country in the ranking, Switzerland, has a share of less than $20 \%$. Moreover, Finnish local authorities receive a substantial amount of user fees, representing more than $8 \%$ of general government revenue and more than a fourth of local government income. The high share of user fees in OECD comparison partly reflects the wide range of services provided by Finnish municipalities. The largest part of user fees relates to utility charges and public transport, with modest fees charged on public health care, while basic education is free (Moisio et al., 2010). User fees provide both revenue and incentives to use resources efficiently, even though these advantages have to be balanced against equity in access to services.

The share of local authorities is even higher in government spending than in revenue in Nordic countries (Figure 2, panel B). The share of local authorities in public spending exceeds $60 \%$ in Denmark and is close to $50 \%$ in Sweden. It is about $40 \%$ in Finland and 30\% in Iceland and Norway. The OECD average is about $24 \%$ and Korea is the only non-Nordic unitary country with a share of local expenditure close to that of Finland.

Figure 2. Local government revenue and spending in $2011^{11}$

As a share of total public revenue and spending
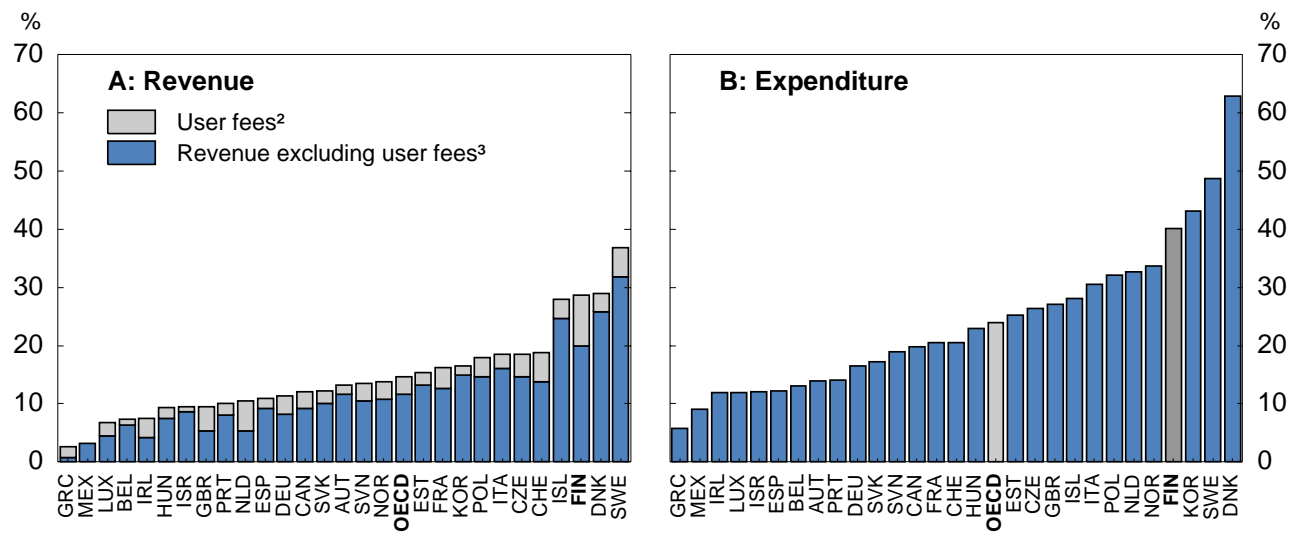

1. Data for Canada, Korea and Mexico refer to 2010. Data for the OECD refer to an unweighted average.

2. Individual payments to public service providers, including collective and private co-payments through insurance schemes, in return for services provided.

3. Excludes grants and subsidies.

Source: OECD Fiscal Decentralisation Database.

The share of local authorities in public final consumption, which reflects more closely the supply of public services, is even higher than their share in overall revenue or spending. About two thirds of public final consumption in Finland takes place at the local level. This is similar to other Nordic countries. Sweden and Denmark are the only two OECD countries where the local share of public consumption is higher than in Finland (Figure 3, panel A).

Local authorities also account for over $70 \%$ of public investment, the second highest share in OECD unitary countries after Japan (Figure 3, panel B). Although the high share of local authorities in public investment in Nordic countries stands out less prominently than for consumption, more than half of public investment is undertaken by local authorities in all Nordics. Finnish municipalities are major investors in education, social services, health care, infrastructure and energy projects. Whereas in many countries fiscal consolidation has led to deep cuts in sub-national public investment, Finnish municipalities have so far been able to sustain high levels of investment (OECD, forthcoming). 
Figure 3. Local government consumption and investment ${ }^{11}$

As a share of total public consumption and investment
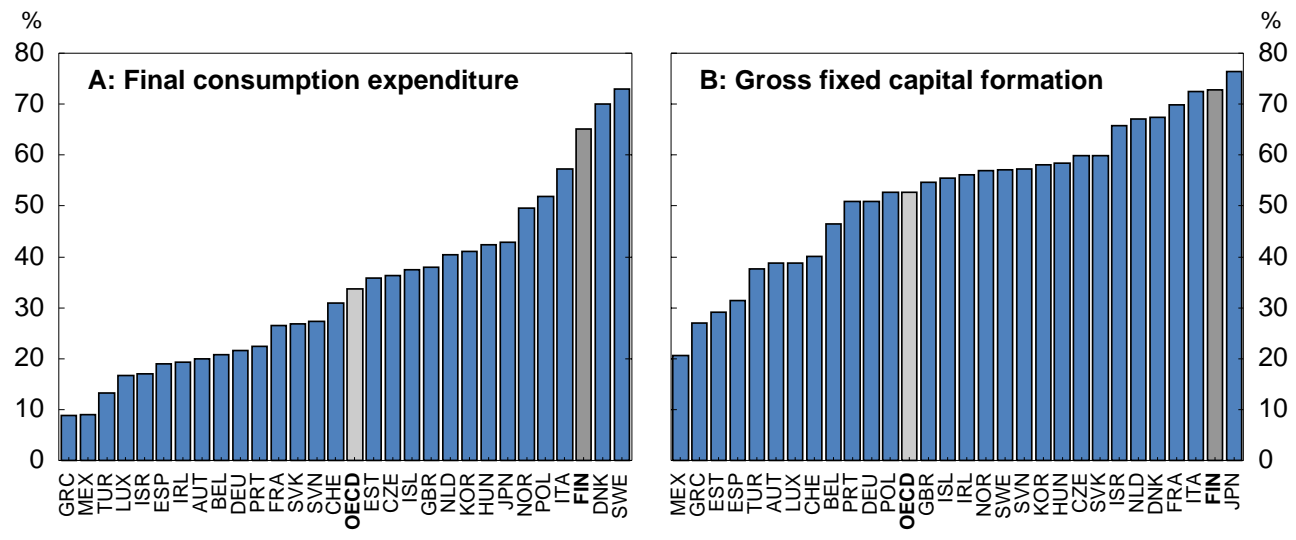

1. In 2011. Data for the OECD refer to an unweighted average.

Source: OECD General Government Accounts.

\section{Education and health care are highly decentralised}

The sub-national share of government expenditure is often used as a measure of sub-national authorities' spending power, but could be misleading where local government spending decisions are strongly influenced by upper-level government regulation (Blöchliger, 2013). Indicators reflecting institutional arrangements may provide a more accurate picture of sub-national autonomy than spending shares, although they are inevitably more subjective. While no overall institutional indicator is currently available for the whole government sector, some have been constructed by the OECD for primary and secondary education and health care. The institutional indicators are based on the level of decision-making for the main functions in the sector and the consistency of responsibility assignment across levels of government (for details, see Gonand et al., 2007 on education and Paris et al., 2010 on health). Both for education and health care, the degree of decentralisation in Finland is among the highest in the OECD (Figure 4). These indicators may even underestimate the responsibilities of the Finnish municipalities relative to other countries, as in some of the latter many tasks are decentralised at state or regional rather than local level. Education is highly decentralised in all Nordic countries, though slightly less so in Norway than others. Regarding health care, Finland is more decentralised than other Nordics. Furthermore, most health care responsibilities in Denmark, Norway and Sweden are devolved to regions or counties rather than municipalities. 

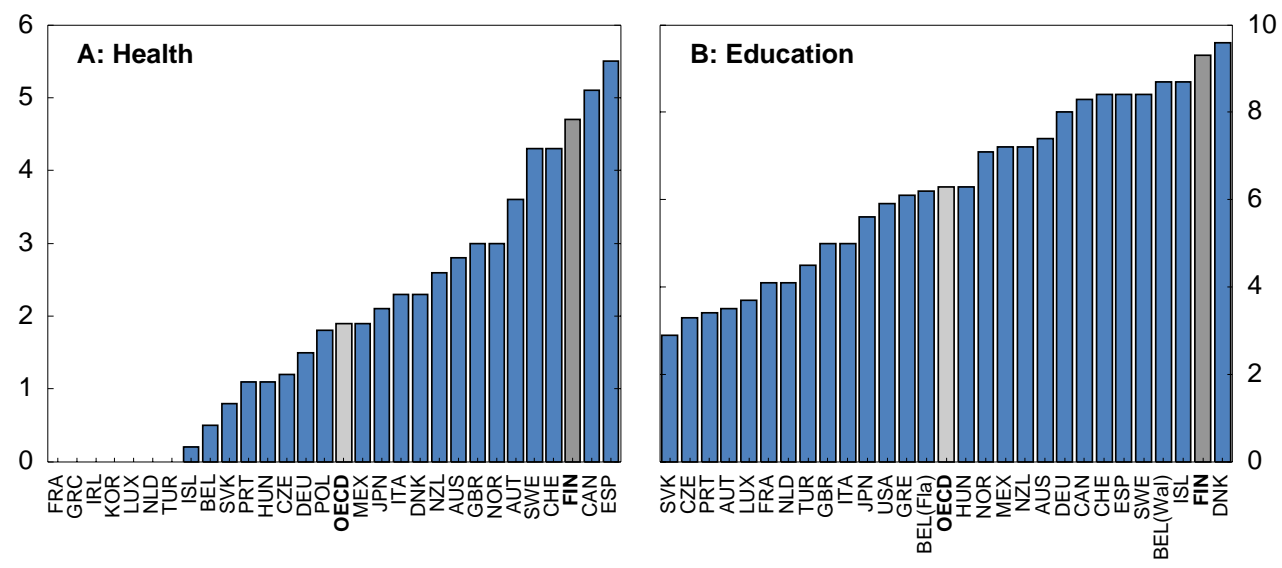

1. Index scale, with a higher value indicating higher decentralisation. A "0" score implies that most key decisions are taken at the central government level. Data for the OECD refer to an unweighted average.

Source: OECD Survey on Health Systems Characteristics 2008-2009; Sutherland, D. and R. Price (2007), OECD Economics Department Working Paper No. 558.

\section{Municipalities have wide responsibilities}

The Finnish government sector is essentially organised around only two tiers, central and municipal (Box 2). In the absence of a regional level of government, as exists in different forms in other Nordic countries, a wide range of responsibilities is devolved to the 320 municipalities, ${ }^{2}$ notably in the areas of education, health and social services and local infrastructure. In particular, municipalities are responsible for providing their residents with:

- Comprehensive and upper secondary schooling, vocational education and training and other education and cultural services;

- Preventive, basic and specialised health care, dental care and healthy living environment promotion;

- Social services for old and disabled people and childcare;

- Town and land-use planning, water and energy supply, waste management, infrastructure maintenance, environmental protection and fire and rescue services.

Municipal responsibilities have been extended over the years. The government has now identified a wide range of local government tasks and obligations that could be reduced, which would save about $0.5 \%$ of GDP. They relate in particular to emergency services, medical archives, education, elderly care and transport (Government of Finland, 2013).

2. Of which 16 in the autonomous region of Åland that is not involved in the municipal reform plans. 


\section{Box 2. The role of the municipal sector in Finland}

Finnish government is organised around only two elected tiers, central and municipal, in contrast with other Nordic countries, which have intermediate levels, such as regions or counties. This structure results in the devolution of a large number of tasks to municipalities. This box outlines the organisation of public administration in Finland, with a focus on the role of municipalities.

Municipal institutions include municipalities, but also joint municipal boards (Figure 5). Joint municipal boards administer joint authorities set up by municipalities to perform specific tasks on a permanent basis. There are currently 184 joint authorities, most of them dealing with health care and education. Joint authorities have no taxing power and are managed by municipality representatives and financed by the member municipalities, mostly based on the use of services by their residents. Joint structures can operate on a local basis - e.g. health care centres - or on a regional scale - e.g. specialised and University hospitals. Joint authorities are mostly created voluntarily by municipalities, but membership is compulsory for specialised (and University) hospital districts, joint authorities for social welfare of the disabled and regional councils, which are assemblies of municipal representatives responsible for regional development, planning and management of structural funds. All municipalities also own companies providing services (for example water, energy or housing, waste management), separately or jointly.

Local state administration includes jurisdictional districts for general and specialised administrative tasks, including police and registry. Local state administration also includes employment service centres and tax offices and courts.

Central government comprises government and ministries, but also a wide range of central offices and agencies, which provide in particular expertise, policy guidance and supervision. At the regional level, the central government is represented by regional state administration. It has been reorganised in 2010 , with the creation of new administrative bodies. Regional State Administrative Agencies (AVIs) are responsible for steering and supervising implementation of national policies regarding basic rights and legal protection, access to basic public services, environmental protection and sustainability, public safety and occupational safety and health. Centres for Economic Development, Transport and the Environment (ELY) are in charge of creating the preconditions for promoting trade and industry, wellfunctioning and safe traffic, a good living environment and sustainable development. There are also other regional offices, for example for defence or tax administration.

Figure 5. Public administration in Finland

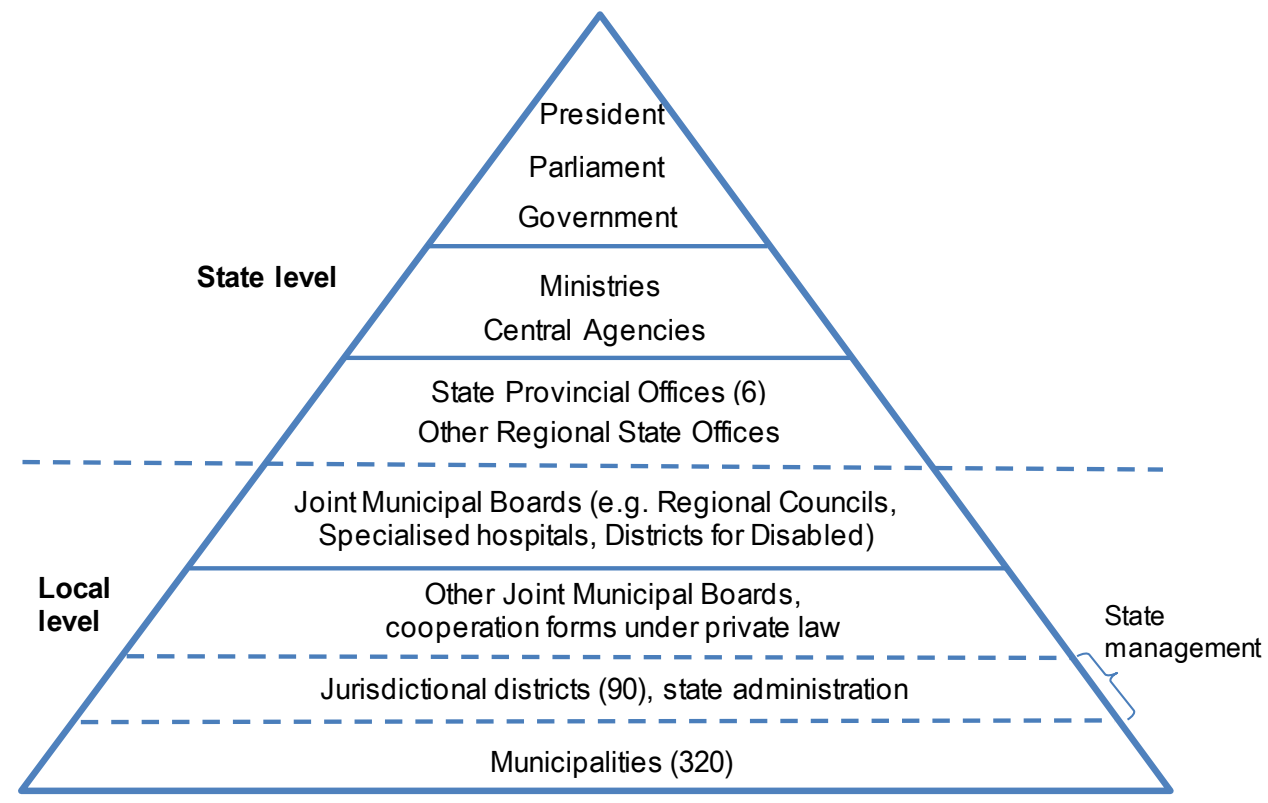

Source: Ministry of Finance. 
The municipal sector accounts for about two-thirds of public consumption and more than a fifth of the total number of employees in the country. Its main sources of revenue are taxes, state grants and sales of goods and services. The main spending items are compensation of employees, purchases of goods and services and investments. About half of total expenditure relates to social welfare and health care and a fourth to education (Figure 6).

Figure 6. Municipal sector expenditures and revenues ${ }^{1}$

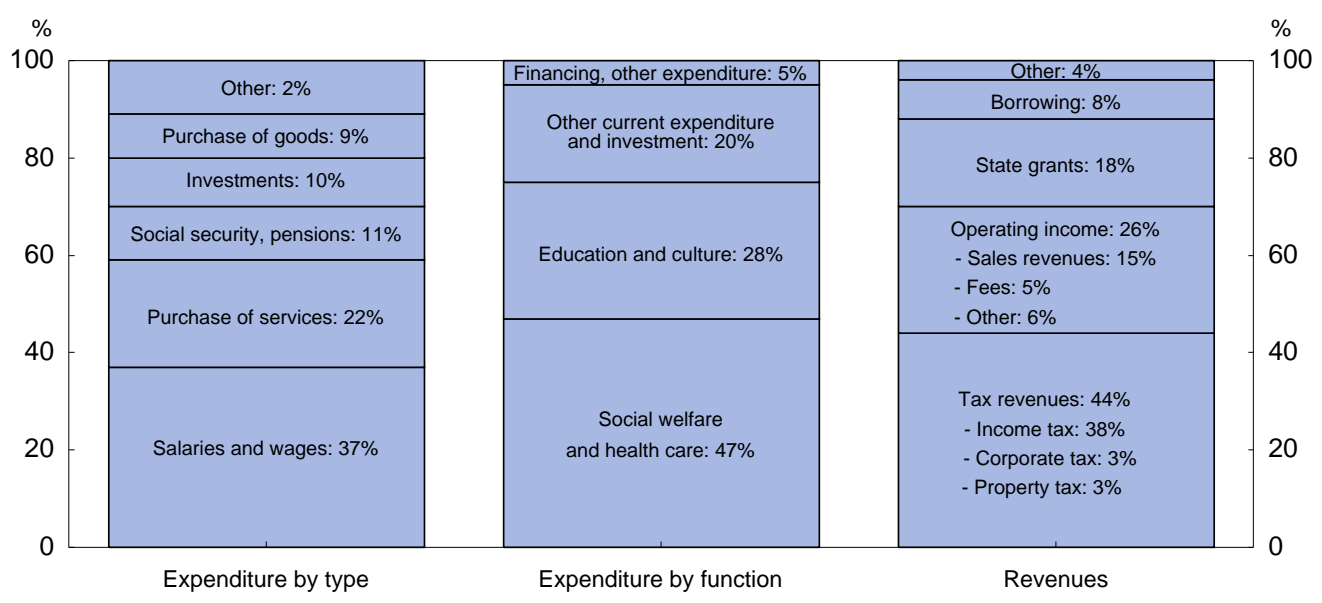

1. Estimate for 2013

Source: Finnish Local and Regional Authorities (Kuntaliitto).

While many of these duties are generally municipal responsibilities across OECD countries, the most complex ones are usually assigned to higher levels of government. This is especially the case for specialised health care, where administration at the municipal level is unusual. There are both advantages and drawbacks to decentralisation. On the one hand, decentralised systems are likely to better respond to local needs and preferences, as local authorities are more directly accountable to local residents than are higher levels of government. Competition between municipalities to attract mobile individuals and firms creates incentives for providing an attractive mix of tax and services. Local administration may also show greater flexibility and allows a wider range of innovation and experimentation than more centralised management. Blöchliger et al. (2013) find that across OECD countries decentralisation, as measured by revenue or spending shares, is positively associated with GDP per capita levels, educational outcomes as measured by international student assessments (PISA) and a higher share of physical and especially human capital investment in general government spending. On the other hand, decentralisation can generate inequalities in the quality of public services provided in different jurisdictions and excessive fragmentation in the delivery of services, likely to generate coordination problems and diseconomies of scale and scope. This is especially the case when a wide range of responsibilities is devolved to small entities, which may lack both expertise to organise, plan or purchase complex services efficiently and bargaining power in negotiations with providers of outsourced services. Externalities may arise when public goods and services are used by residents outside municipal boundaries. Local authorities may also face conflicts of interest, when they are producers of services employing large numbers of local staff.

\section{Municipalities tend to be small relative to the extent of their responsibilities}

Finland's 320 municipalities have an average population of about 17000 , which is not especially small compared to other continental Europe countries. Most Southern and Eastern Europe countries, Austria, France and Germany have on average smaller municipalities than Finland (Figure 7, panel A). But these countries also devolve fewer tasks to municipalities (Fox and Gurley, 2006). 
Figure 7. Municipality population in 2012
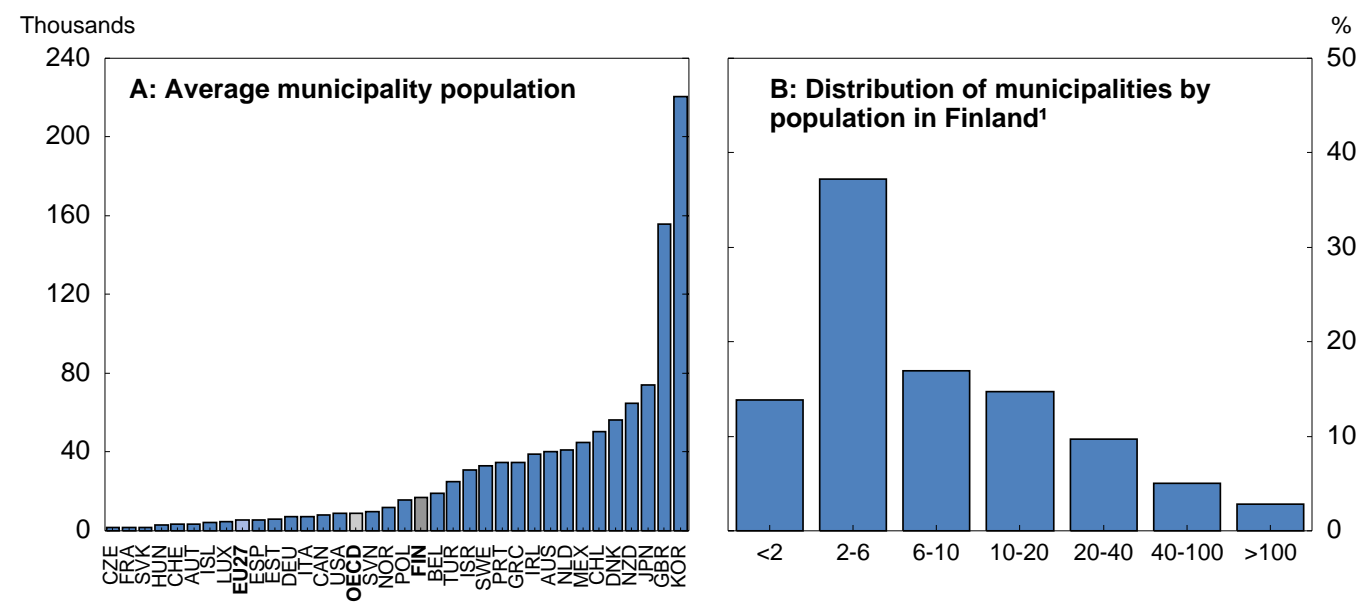

1. In thousands of inhabitants. Data for the OECD refer to an unweighted average.

Source: OECD Key Figures on Subnational Governments in OECD countries - 2012 data (2013); Statistics Finland and OECD calculations.

Municipalities play a greater role in Nordic countries, and more so in Finland in the absence of powerful regional institutions. Compared to other Nordic countries, Finnish municipalities are significantly larger than in Iceland and Norway, but much smaller than in Denmark and Sweden. Before the 2007 reform, the average population of Danish municipalities was already around 20000 and it now well exceeds 50 000. The last significant phase of municipal consolidation in Sweden ended in the mid-1970s, by which time the average population was close to 30000 . The nationwide average hides large differences across Finnish municipalities, whose size ranges from a few hundred to about 600000 inhabitants. The median size is around 6000 . Nearly $40 \%$ of municipalities have between 2000 and 6000 inhabitants. Only 16\% have a population over 20000 (Figure 7, panel B).

Municipal cooperation to provide some services jointly is well developed in Finland. For example, some small municipalities share a health centre (there were 162 health centres for 336 municipalities in 2011). Specialised health care is handled by hospital districts, which are managed and financed by joint municipal boards (federations of municipalities). While health care accounts for three-quarters of total joint-authority expenditure, municipal cooperation is also important in other areas, including education, waste management and water supply. Cooperation takes different forms, allowing flexible responses to local needs. Examples include joint authorities set up by municipalities to perform specific tasks on a permanent basis (e.g. hospital districts, health centres, districts for vocational education); the "host municipality model", where a municipality manages some functions for a group of municipalities; and contractual cooperation, frequent in utility services and education. Municipal cooperation solves many scale and externality problems and is generally working quite well in Finland. Nevertheless, enhancing cooperation is unlikely to be sufficient to meet the challenges associated with population ageing and eroding tax bases in many municipalities (Moisio et al., 2010). Cooperation also seems associated with a lack of transparency and accountability in decision making, which progressively shifts from elected representatives to professionals (Moisio, 2012).

Transfers from central government to municipalities are used to ensure, as far as possible, equity in access to social services, health care and education, as well as in taxation across the country. The Finnish cost and revenue equalisation scheme is one of the largest in the OECD as a share of government expenditure and GDP (Blöchliger et al., 2007). Since 1993, municipalities receive non-earmarked block grants, leaving them ample autonomy in spending decisions, even if limited by national standards and 
regulations. The transfer amounts are set to meet estimated population needs and equalise revenue. The weight of cost factors in the determination of transfers is about $90 \%$, which contrasts with Sweden and Denmark, where revenue equalisation is dominant (Blöchliger et al., 2007). This may make the Finnish system more difficult to administer and theoretically more prone to manipulation although there is no evidence to that effect (Moisio et al., 2010). Population needs are estimated using a range of criteria for each type of spending. Some criteria aim at compensating for higher service costs due to the size, age structure, density of population and isolation of a municipality. Some apply to several service sectors. Others are specific to one sector, for example morbidity in health and unemployment in social services. Additional grants go to the bilingual municipalities, the archipelago area and Sami regions. All grants are now administered by the Ministry of Finance, except for those related to upper secondary schooling and vocational education.

An equalisation system redistributes tax revenue, via state transfers across Finnish municipalities, according to their tax-raising potential. The potential tax revenue is computed by applying the country average tax rates to the municipal tax bases. Municipalities with a potential tax revenue per capita below $91.86 \%$ of the national average receive the difference in the form of added transfers from the state. The municipalities with a potential tax revenue above that threshold see their calculated state transfers reduced by $37 \%$ of the tax revenue in excess of the threshold. Currently 61 of the 304 municipalities outside the autonomous region of Åland are above the threshold. While municipalities below the threshold would not benefit from an increase in tax revenue, which would be offset by lower grants, those above the threshold retain $63 \%$ of any additional revenue collection. Such asymmetry may reduce incentives for weaker municipalities to develop their activity and tax base, leading to widening regional differences (Blöchliger and Pinero Campos, 2011).

\section{Local finances are deteriorating and public services becoming increasingly uneven}

\section{The aggregate local government deficit and debt are rising}

Central government currently accounts for the largest part of the general government deficit, as its revenue and spending are most sensitive to the business cycle. Nevertheless the contribution of local government is also significant (Figure 8, panel A). Moreover, the local contribution is of a more structural nature. While a strong economic recovery would reduce the central government deficit significantly, the impact on municipalities would be much more limited, especially as ageing and other factors are likely to continue pushing up health care and social expenses (see De la Maisonneuve et al., 2014). Local government consumption has outpaced that of central government since the early 2000s (Figure 8, panel B). Despite increases in tax revenues and central government transfers over the period, the local government sector has run a deficit of $1 / 2$ per cent of GDP on average. The deficit has increased significantly since 2010. According to the Ministry of Finance, the deficit is expected to remain around 1\% of GDP in the coming years, as a result of cuts in central government grants and continued pressure on spending. 
Figure 8. Trends in government finances
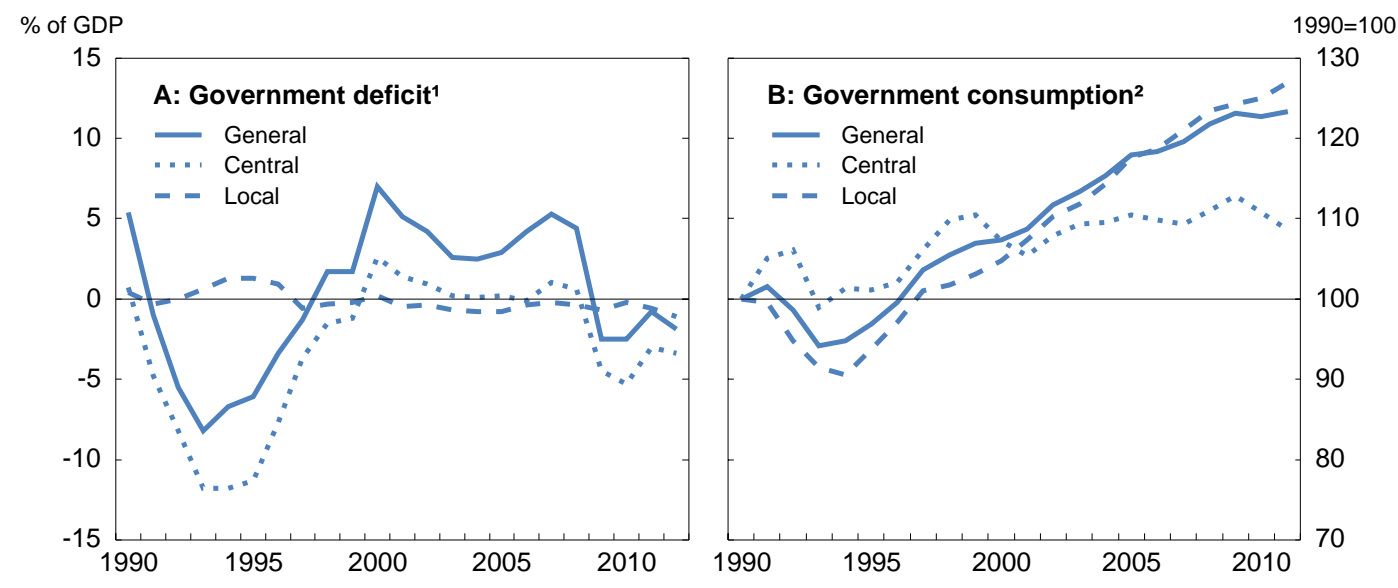

1. Data for 2011 and 2012 are preliminary.

2. In real terms.

Source: Statistics Finland.

Deteriorating fiscal positions are pushing municipalities to raise local taxes or to increase borrowing. About a third of municipalities have hiked their local income tax rate in 2013. While there may be some scope to increase local taxes further, especially the least distortive ones on property, the overall level of taxation in Finland is already high by OECD standards, suggesting that tackling deficits mainly by raising taxes may become increasingly difficult. In addition, higher tax increases in municipalities operating in a challenging environment than in more prosperous ones may further widen regional economic differences. Hence, maintaining high-quality public services will require structural reforms.

Figure 9. Local government debt

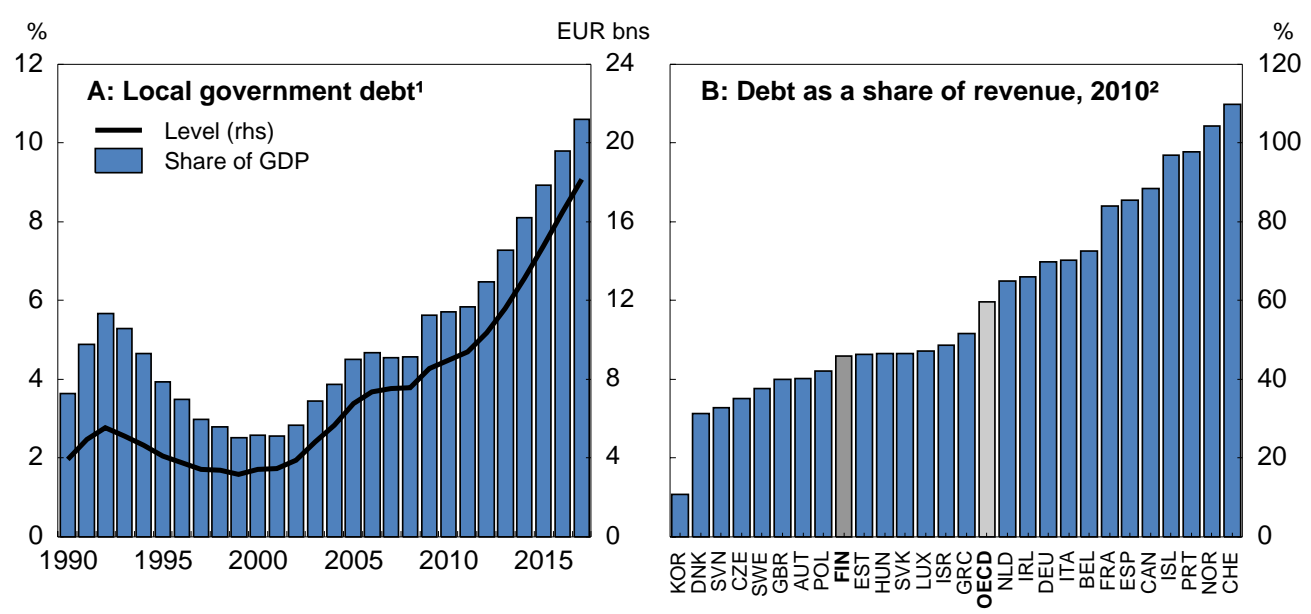

1. Maastricht definition. Data for 2012 are preliminary, and from 2013 are projections. The series in levels is adjusted using the GDP deflator.

2. Data for the OECD refer to an unweighted average.

Source: Statistics Finland and OECD fiscal decentralisation database. 
Local government debt has increased steadily since the beginning of the 2000 s, from less than $3 \%$ of GDP in 2000 to about 7\% in 2013. According to Ministry of Finance projections, it will reach nearly $11 \%$ by 2017 (Figure 9, panel A). This remains relatively modest, both in relation to central government debt and in international perspective. Local government debt accounts for a fairly modest share of local revenue (Figure 9, panel B). Nevertheless, the rapid growth in debt calls for caution over medium to long-term sustainability, even if part of the projected increases is related to cuts in central government grants. As debt rises, municipalities are becoming more vulnerable to increases in interest rates from currently exceptionally low levels. Furthermore, inability to control increases in sub-national debt can trigger adverse reactions from financial markets and raise the cost of borrowing, both for municipalities and central government.

\section{Differences in the financial situation of municipalities are widening}

Aggregated local government data hide divergent fiscal fortunes across municipalities, reflecting both diversity in population needs and operating environment and differences in efficiency (Moisio, 2002). The distribution of municipal debt has widened over the past decade, even before the global economic and financial crisis (Figure 10, panel A). Differences in revenue per capita across municipalities have increased (Figure 10, panel B). Some municipalities suffered large drops in revenue, notably as a result of falls in corporate profits and plant closures eroding tax revenue (Box 3). Differences in net expenditure per capita of municipalities have also increased markedly, especially for health care and social services (Figure 10, panel C and D). Municipal expenditure per capita in remote areas is higher than elsewhere, as in other countries with low density areas (Kitchen and Slack, 2006). Average expenditure in the $20 \%$ of municipalities with the lowest population density is $17 \%$ above the average in the remaining $80 \%$. 
Figure 10. Local government finances ${ }^{1}$

Distribution of municipalities ${ }^{2}$
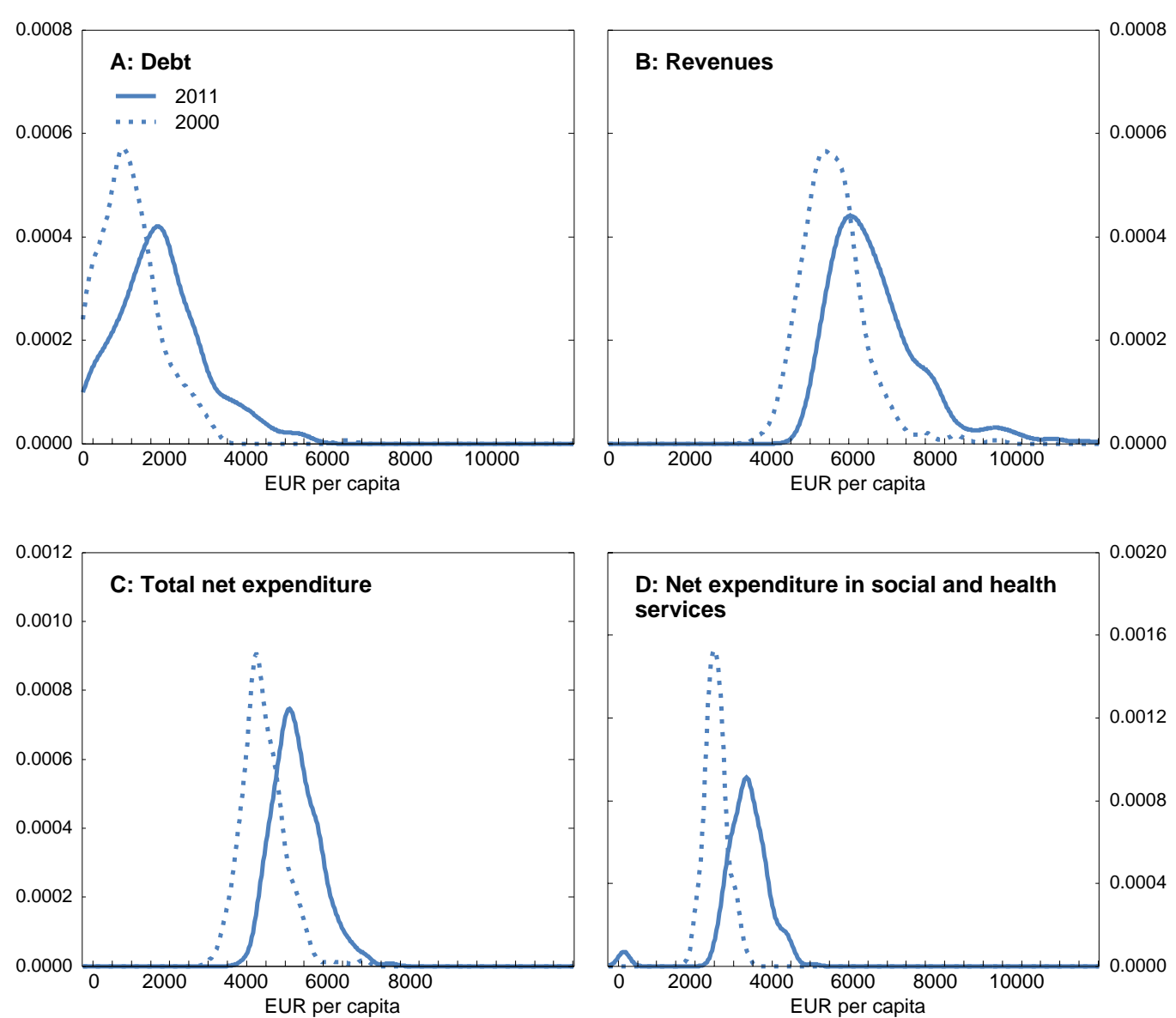

1. Deflated by the government consumption price index.

2. Kernel density.

Source: OECD database on sub-national finances (Directorate for Public Governance and Territorial Development), and OECD calculations.

A large share of municipal debt (currently about 80\%) is financed through Municipal Finance (MuniFin), a fully publicly-owned provider of financial services to local governments. MuniFin debt is guaranteed by the Municipal Guarantee Board, which includes most Finnish municipalities. It enjoys a triple-A rating and has benefitted from Finland's safe haven status in recent years. A potential drawback of the joint liability of municipalities and the associated low credit risk is a lack of discrimination between borrowers. However, this is not specific to Finland, as market discipline on sub-national public authorities is almost absent outside the United States and Canada (Moisio, 2012). MuniFin has conservative risk management policies, in particular allowing no foreign currency risk and restricting the use of derivatives to hedging, which proved wise in the recent financial turmoil. 


\section{Box 3. The municipality of Salo: adjusting to the closure of the Nokia plant}

Salo is a city of about 55000 inhabitants in south-west Finland. The current municipality is the result of the merger on 1 January 2009 of the core of Salo with nine surrounding municipalities. Salo used to house a key Nokia mobile phone production site, which employed more than 5000 workers at its peak, but manufacturing stopped in 2012. Nokia retained a research unit in Salo, with about 1200 workers, which is now being taken over by Microsoft. The fall in Nokia's profits caused a sharp drop in the municipality's corporate tax revenue, which fell from nearly $€ 60$ million in 2010 (about $28 \%$ of total tax revenue) to less than $€ 9$ million in 2012 . Downsizing at Nokia and eventually the plant's closure resulted in a sharp rise in the unemployment rate, which jumped from less than $6 \%$ in mid-2008 to more than $14 \%$ in early 2013 . The municipality of Salo, with support from the State, is actively implementing strategies to deal with this challenging situation.

The 2009 merger has improved Salo's ability to deal with the current situation, as one large municipality is more flexible to reorganise in response to shocks than ten smaller ones with numerous cooperation agreements, and a bigger municipality has greater influence at the provincial and national level. As usual following mergers, operating expenses rose sharply in 2010, reflecting in particular harmonisation of salaries to the highest levels, but decelerated in 2011 and 2012, before falling slightly in 2013. While the merger improves resource allocation, duplication still remains, especially because employment protection for five years following the merger delayed reorganisation. The expiry of the employment guarantee in early 2014 will facilitate the reshuffling of municipal services. This will require care to preserve the quality of essential public services. In addition, support will be needed to help employees made redundant to find new jobs (e.g. job-search assistance, training).

The Ministry of Employment and the Economy granted Salo the status of "rapid structural change area" from September 2009 to end-2013. The status gives access to financing, including European Union funds, for interventions in various fields, including labour market programmes and support for entrepreneurship. However, to be effective, support will need to go beyond 2013. The Municipality of Salo is cooperating with Nokia and the government to help laid-off workers find new jobs, in particular through job-search assistance, education and training and support for startups. Actions are taken to maintain working ability and prevent social exclusion. Reemployment of laid-off workers is challenging, as many are production workers, for which there is less demand than for white-collar employees. A wide range of measures similar to those taken in Salo to support laid-off workers seem to have facilitated reemployment after the closure of a plant of the manufacturer of electronics and telecommunication equipment Perlos in North Karelia in 2007 , although better labour market conditions than now were also helpful (Jolkkonen et al., 2012).

The Salo Business Service Center, owned by the City of Salo, offers business services to small and medium enterprises (SMEs), support for international expansion and advice for start-ups. It also promotes the city as a place to invest, benefitting from a skilled workforce, excellent logistic connections and a business-friendly environment. While overcoming the impact of the closure of the Nokia plant will take time, an extensive network of SMEs holds promises for Salo's future, as business expands in innovative industries such as eco-effective lighting, marine industry, solar energy and healthcare technologies.

Some municipalities have been relying increasingly on central government transfers, with the distribution of transfers from central government to municipalities widening significantly. Cuts in central government grants by more than $10 \%$ at the 2015 horizon will put further pressure on municipalities to rein in spending or raise taxes. Over the medium to long term, ensuring the sustainability of municipal finances while preserving the quality of public services will inevitably require efficiency gains. Municipal consolidation and reorganisation of public services should play a major role in generating such gains.

\section{Ensuring equal access to services across the country is challenging}

In addition to the wide variation in the cost of providing public services across municipalities, there is increasing concern that some municipalities are struggling to provide adequate services. While providing public services is mainly a municipal responsibility, there is a strong commitment by central government to ensure equal access to services across the country through financial transfers and national standards and regulation. Although municipalities retain large autonomy in organising services, more than three quarters of local government expenditure relates to tasks mandated by central government. The principle of equal access to services also enjoys wide public support. Nevertheless, there is tension between self-governance 
and equal provision of services. Municipalities often complain that national standards are imposing an excessive financial burden on them. Moisio et al. (2010) argue that "the burden of tasks of the municipalities should no longer be increased" and that it is perhaps time to start a political discussion on the distribution of tasks between local authorities, central government and the private sector. The government is taking steps to avoid overstretching local finances through excessive demands, unmatched by adequate funding (Box 1).

Complaints about inadequate public services in some municipalities, notably in elderly care, rose in the 2000s, prompting the government to strengthen central control on local social care provision. A project to restructure local government and services (PARAS) was launched in 2005 to reinforce the capacity of municipalities to deliver services, through mergers and enhanced cooperation. Although the project has led to significant municipal consolidation and enhanced cooperation, it seems to have achieved only modest results in terms of improvement in service provision (Kröger, 2011). The economic downturn has further eroded financial resources available to finance public services, while population ageing is increasing demand. Hence, further reform is warranted to ensure efficient provision of services across the country.

Health care is an area where providing services according to national standards is more and more difficult for some municipalities, as increasing specialisation and technological developments push up fixed costs and shortages of qualified personnel complicate recruitment. As an illustration, the overall shortage of doctors in municipal health centres was estimated at $6 \%$ in 2011, but reached $22 \%$ in the worst affected region (Finnish Medical Association, 2011). Shortages of health personnel result in inequality in access to health care, as employees can use occupational health care and private consultations are available to those who can afford large co-payments. Waiting times are still a major problem in local health care services, even though they have been reduced in recent years (Vuorenkoski et al., 2008). Inequality in access to health care is high by OECD standards and likely contributes to disparities in health status (OECD, 2012).

\section{The fiscal framework could be strengthened}

A solid fiscal framework is essential to ensure efficiency and fiscal discipline at all levels of government. Factors likely to influence local and general government fiscal outcomes include the degree of tax autonomy enjoyed by local authorities, the type of taxes levied by different levels of government, the design of intra-government transfers and the strictness of central government control over local spending.

Finnish municipalities enjoy extensive fiscal autonomy. They may freely set the level of the municipal income tax rate (a flat rate) and can set the property tax rate within a range defined by central government. Municipalities have broad discretion over spending decisions, even though national standards and regulations restrict local choice. The current budget needs to be balanced over a four-year period. There are no expenditure ceilings. There are also no limits on municipal borrowing or debt levels, which is unusual in the OECD, with the few exceptions including Austria and Norway (Sutherland et al., 2005). According to an OECD indicator of tax autonomy, which summarises information on rules and regulations applying to local taxation, Finland ranks third among OECD countries for tax autonomy of local authorities, behind Sweden and Denmark and on a par with Iceland (Blöchliger and Pinero Campos, 2011). Fiscal autonomy can have both advantages and drawbacks, depending on the institutional settings, the design of rules and how they are implemented. It can favour responsiveness to local preferences, flexibility, allocative efficiency and ability to cope with economic shocks. However, extensive collection of taxes by local authorities results in the inclusion of volatile items in local tax bases, with risks of pro-cyclicality in fiscal policy and negative effects on service provision and fiscal sustainability. Fiscal autonomy may also create inequalities and foster negative tax competition. 
ECO/WKP(2014)17

\section{The tax mix could be improved}

The tax mix has important implications for the efficiency and stability of the fiscal system. The main source of local tax revenue is the municipal income tax, which represents nearly $40 \%$ of total municipal income (Figure 6). Municipalities also raise property taxes and receive a share of corporate income taxes. The theoretical literature on fiscal federalism posits that local taxation should be "benefit taxation", where benefits to residents derived from public services match the taxes they pay (Tiebout, 1956). The extensive provision by municipalities of welfare services, which are redistributive in nature, prevents the full application of this principle in Finland. User fees can be collected for goods and services consumed individually. For public goods, which are consumed collectively, few taxes come close to a "benefit tax". Hence, a large local government sector imposes recourse to other types of taxes. Furthermore, "benefit taxation" is hampered by spillovers - i.e. use of public goods and services produced by other municipalities than the one where taxes are paid - which are excluded by assumption in the mainstream literature. Nevertheless, shifting the tax mix more towards property taxes and away from volatile corporate income tax could improve the efficiency and stability of the fiscal system.

Property taxes are the closest to "benefit taxes" (Borge and Rattsø, 2012). They tend to distort resource allocation less than other taxes and hence damp growth less (Arnold et al., 2011). In addition, recurrent residential property taxes, if closely reflecting property values, could reduce housing market volatility (Muellbauer, 2006). As it touches largely immovable tax bases, reliance on property taxes also reduces opportunities for harmful tax competition, especially as taxes tend to be capitalised in property prices (Blöchliger and Pinero Campos, 2011). Property taxes account for a modest share of total tax revenue across OECD countries. Nevertheless, they make up a sizeable share of local taxes in countries like Canada, France, the United States or the United Kingdom. In Nordic countries, property taxes account for a small share of total local revenue - less than 3\% in Finland. As a share of GDP, they stand at $1.1 \%$, as against an OECD average of $1.8 \%$, suggesting that there is room for increasing their weight in local taxation. Furthermore, high-income municipalities which benefit most from corporate tax revenue tend to set low property tax rates. Central government has been encouraging greater reliance on property taxes. In 2010 , the range within which local governments may set property tax rates was increased from $0.5 \%-1 \%$ to $0.6 \%-1.35 \%$. A revision to bring real estate valuations closer to market values in 2014 should increase tax income by 100 million euros (Ministry of Finance, 2013).

Directing part of corporate income tax revenue to municipalities may encourage them to create an attractive business environment in order to develop their tax base. Competition between municipalities to attract firms may lead to better public services. However, corporate taxes are very volatile, making them ill-suited to fund public services, even though they on average account for only $3 \%$ of municipal revenue and flexible fiscal rules and ability to borrow attenuate this problem. Higher revenue almost inevitably tends to push up public spending and the temporary nature of some receipts is often underestimated. A sharp fall in corporate tax receipts may force municipalities to cut spending drastically, especially as it is most likely to be accompanied by lower receipts from personal income taxes and higher spending on social services, as the earnings base contracts and unemployment rises. Municipalities facing the closure of large plants are particularly vulnerable (Box 3). Another motivation for reducing dependence on corporate taxes is that these are likely to continue being eroded by international tax competition, as illustrated by the cut in the corporate tax rate from $24.5 \%$ to $20 \%$ in 2014 following similar moves in Denmark and Sweden. Finnish municipalities are strongly resisting any attempt to remove corporate taxes from their tax base, as they are concerned losses would not be compensated by higher state grants (Moisio et al., 2010). Nevertheless, attempts to reduce the share of corporate taxes in local revenue in favour of more stable property taxes should be pursued. 


\section{Tighter fiscal rules could be considered}

Devolving a wide range of spending decisions to local authorities, while ensuring a high degree of equality in taxation and service provision across jurisdictions, may result in excessive spending due to the "common pool problem" (Ter-Minassian, 2007). Redistribution implies that part of local expenditure is funded by a national pool. This may lead to underestimating public services costs at the local level, as only part of these costs are matched by taxes, and thereby create moral hazard (Moisio, 2012). Expectations of central government bailout in case of trouble may also reduce prudence. Provision of essential public services by local authorities raises the probability of bailout (Ter-Minassian, 2007). In Finland, municipalities facing economic duress may receive discretionary grants from central government. Discretionary grants amount to $€ 20$ million per year, roughly $0.02 \%$ of annual state current transfers to municipalities. Discretionary state grants, however, are accompanied by stringent adjustment programmes, imposing tax increases, sale of municipal property, cuts in personnel, postponement of investments or reorganisation of service provision. Between 2006 and 2011, 36 municipalities entered such a programme, which in 17 cases was associated with voluntary merger.

A stronger fiscal framework could further mitigate common pool and moral hazard problems, in particular through the design of intra-government transfers and fiscal rules. In the context of the implementation of the EU fiscal compact, the government decided in spring 2013 to establish a civil service working group to develop the Basic Public Services Programme procedure, with the aim of enhancing the macroeconomic steering of local government. This working group examines in particular the possibility to limit the central government's ability to increase municipal responsibilities and expenditures without also allocating full financing. Blöchliger et al. (2007) suggest that redistribution between municipalities (horizontal transfers) is less likely to generate budget problems than transfers from central government to municipalities (vertical transfers). As noted above, the Finnish transfer system is both large and tilted towards vertical transfers. The grant system has been criticised as too complex, opaque and based on formulas using inadequate indicators of needs (Moisio et al., 2010). Reform of the system is currently under preparation, with the objective of simplifying criteria and calculations, improving transparency and ensuring neutrality in merger cases. Municipal consolidation will also reduce the need for redistribution through grants, as municipalities will become more homogenous.

Fiscal rules may mitigate moral hazard and ensure fiscal sustainability. However, they may also have negative side effects, such as weakening local fiscal responsibility, lowering allocative efficiency and reducing flexibility to adjust to the economic cycle and temporary shocks. The OECD Fiscal Federalism Network has developed an indicator of sub-central government fiscal rules, which takes into account these various dimensions. Table 1 shows how Finland compares with other unitary countries with strong local government, including other Nordics. On the composite indicator, Finland scores below Norway, but above Denmark and Sweden. Finnish fiscal rules appear particularly weak at ensuring debt sustainability. They are also quite weak at restraining public spending, although less so than in Norway and Sweden. On the other hand, they strongly support allocative efficiency and provide high flexibility to cope with shocks. Setting an expenditure ceiling could improve expenditure control and debt sustainability, with limited negative side effects on ability to cope with shocks and allocative efficiency. Broadening the budget balance rule by including the capital account in the target would enhance deficit control and foster efficient allocation of public resources, as the current exclusion of capital outlays from the budget target may lead to investments with low social return (Fredriksen, 2013). A set of Principles on Effective Public Investment is to be adopted by the OECD Council in early 2014, which will provide further guidance on coordinating investment decisions between levels of government, strengthening capacity for public investment and ensuring proper framework conditions at all levels of government (OECD, 2013). 
Table 1. Sub-central government fiscal rules indicator in selected countries ${ }^{1}$

2011

\begin{tabular}{|c|c|c|c|c|c|}
\hline & \multirow[b]{2}{*}{$\begin{array}{l}\text { Composite } \\
\text { indicator }\end{array}$} & \multicolumn{4}{|c|}{ Sub-indices } \\
\hline & & $\begin{array}{l}\text { Restraining the size } \\
\text { of the public sector }\end{array}$ & $\begin{array}{c}\text { Supporting allocative } \\
\text { efficiency }\end{array}$ & $\begin{array}{l}\text { Ensuring debt } \\
\text { sustainability }\end{array}$ & $\begin{array}{l}\text { Coping with } \\
\text { shocks }\end{array}$ \\
\hline Korea & 5.9 & 2.5 & 8.0 & 5.8 & 2.0 \\
\hline Norway & 5.6 & 2.6 & 7.8 & 7.8 & 3.0 \\
\hline Czech Republic & 5.4 & 3.6 & 9.4 & 3.5 & 5.0 \\
\hline Finland & 5.2 & 3.1 & 7.8 & 3.6 & 6.3 \\
\hline Denmark & 4.8 & 3.5 & 4.5 & 7.4 & 3.6 \\
\hline Poland & 4.3 & 3.2 & 6.6 & 6.8 & 1.8 \\
\hline Sweden & 4.3 & 2.4 & 6.7 & 4.0 & 4.2 \\
\hline Estonia & 4.1 & 2.5 & 4.4 & 7.5 & 2.0 \\
\hline
\end{tabular}

1. Values are normalised to range between 0 and 10 , with a higher value indicating more stringent rules.

Source: Fredriksen, K. (2013), OECD Economics Department Working Paper No. 1071.

The extension since 2011 of the fiscal policy monitoring and evaluation functions of the National Audit Office, which reports to Parliament, strengthened the provision of independent assessments of general government finances. Financial reporting by municipalities follows standards which are close to those of private accounting. Accounts of private law entities (companies, associations, cooperatives and foundations) controlled by a municipality are consolidated in its financial statement. Nevertheless, efforts to produce and disseminate local government accounts consistent with those of central government should continue (Fredriksen, 2013). Statistics Finland is already working on improving timeliness, developing quarterly statistics on municipal finances and better recording implicit liabilities. Monitoring the quality and efficiency of public services is essential. Benchmarking of providers of public services could be developed further to encourage best practice (OECD, 2012). While improving the fiscal framework may help contain expenditure, more fundamental challenges need to be addressed to ensure efficient delivery of high-quality public services.

\section{The reform of municipalities has the potential to generate efficiency gains in public services}

\section{The government is promoting an ambitious reform}

The government which took office in June 2011 has committed to implementing a comprehensive nationwide reform of municipalities to enhance productivity and effectiveness in the delivery of public services. Mergers will initially be voluntary. Municipal councils are currently discussing merger plans and have an obligation to provide reports and proposals by July 2014, for mergers to be implemented between 2015 and 2017. The government is considering imposing mergers in the 10 or so main urban centres outside the Helsinki Metropolitan Area if municipalities fail to come up with sufficiently ambitious consolidation plans.

\section{Evidence from OECD countries points to potential benefits of merging small municipalities}

Municipal consolidation has taken place in many OECD countries in the past (Box 4). Although important differences in the structure of government and responsibilities devolved to municipalities across countries need to be kept in mind, the literature analysing the impact of mergers provides some useful lessons. 


\section{Box 4. Municipal mergers in OECD countries}

Municipal mergers have taken place in many OECD countries, driven by various objectives, including improving coordination within a metropolitan area, enhancing strategic planning, promoting development and achieving economies of scale and efficiency gains in administration and provision of public services. Early cases include the United States (notably Philadelphia and New York), Japan and Portugal, back in the second half of the 19th century. Large-scale consolidation, generally compulsory and often reducing the number of municipalities by more than half, took place from the 1950s to the 1970s in Austria, Belgium, Canada, Denmark, Germany, Japan, the Netherlands, Norway, Sweden and the United Kingdom. Amalgamation was also achieved in the 1989 New Zealand local government reform and in Australia since the early 1990s, on a compulsory or voluntary basis depending on states. Few municipal mergers occurred over the past 50 years in the United States, where cooperation through special purpose entities has been privileged and consolidation mainly concerned school districts (Fox and Gurley, 2006).

Mergers of municipalities within the Toronto and Montreal metropolitan areas were imposed by the provincial government of Ontario in 1998 and Quebec in 2002 despite strong local opposition, but seem to have achieved neither significant cost savings nor improvements in regional coordination (Slack and Bird, 2012; Smith, 2007). In Montreal, following local referendums, 15 of the 27 merged municipalities regained independence in 2006. The cooperation approach followed by British Columbia seems to have been more successful than amalgamation strategies followed by other provinces at creating flexible and efficient public management structures (McLean et al., 2006).

Eastern European countries have followed diverging paths after returning to democracy. The Czech Republic, Estonia, Hungary and Poland have favoured the cooperation approach, while Latvia and Lithuania have embarked on large scale consolidation, with mixed results.

Luxembourg launched a project in 2008 to reduce the number of municipalities from 116 to 71 by 2017 and there was a cut to 106 in January 2012. In Greece, the "Kallikratis reform" reduced the number of municipalities from 1033 to 325 in 2010. The "Capodistrias plan" had already reduced the number of Greek municipalities from 5825 to 1033 in 1997. Reforms are underway in other countries, including Ireland and the Netherlands.

Successive waves of mergers have reduced drastically the number of municipalities in Nordic countries. The number of municipalities in Sweden was brought down from about 2500 to around 1000 in 1952 and to 278 in 1974 . A few subsequent splits raised their number to 290. The number of Norwegian municipalities was cut from about 750 to around 450 in the early 1960s and 428 in 2013. Denmark went from more than a thousand municipalities in the 1960s to about 275 in 1970 and to 98 in 2007 . The number of municipalities in Iceland, where mergers are mainly voluntary, shrank from 229 in 1950 to 170 in 1995, 124 in 2000 and 74 in 2013. In Finland, although there has been no large amalgamation plan, voluntary mergers reduced the number of municipalities from 560 in 1945 to 460 in 1990 and 320 today (Borge and Ratts $\varnothing, 2012$ ).

There is international evidence of a U-shaped relationship between size and overall cost of public services per capita. Municipalities with less than 20000 to 25000 inhabitants or with more than 250000 appear less efficient than those within that range (McKinlay Douglas Limited, 2006; Holzer et al., 2009). Small municipalities tend to suffer from diseconomies of scale, although these tend to be confined to specific areas, in particular specialised and capital-intensive services. Beyond a certain point, larger municipalities tend to become less efficient, presumably because they are more complex to administer. In Finland, some $84 \%$ of municipalities have less than 20000 inhabitants, so there is ample room for municipal consolidation. Furthermore, as explained below, the optimal size of municipalities varies across functions and the wide range of responsibilities devolved to municipalities in Finland may call for larger entities than in countries where municipal duties are more restricted.

A U-shaped relationship between the size of municipalities and the cost of public services per capita is also observed in Finland. Costs appear to be lowest in the 20000 to 40000 inhabitants range, consistent with findings from the international literature. For municipalities with less than 10000 inhabitants, the dispersion of spending per capita is wide (Figure 11, panel A). Using median instead of average spending avoids giving too much weight to outliers and yields a similar U-shaped curve (Figure 11, panel B). Intervals between the first and fifth quintiles - which remove the $20 \%$ of municipalities with highest and 
lowest spending per capita - clearly confirm the U-shaped relation between size and costs per capita. This empirical evidence argues strongly in favour of merging municipalities to reach a population of at least 20000 , at least outside remote areas.

Figure 11. Cost of public services by municipality size

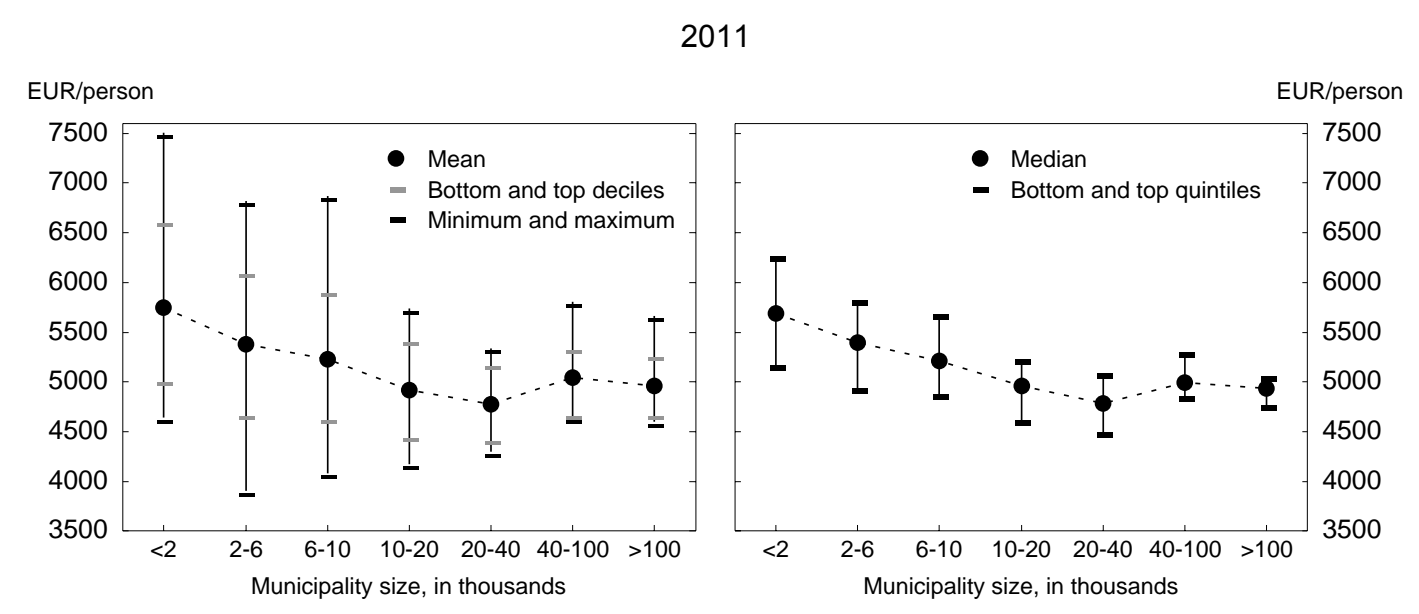

Source: OECD questionnaire (Directorate for Public Governance and Territorial Development) and OECD calculations.

Building robust municipalities in the main urban centres would also help achieve the regional development targets of strengthening regions' competitiveness and vitality and promoting well-being and environmental sustainability. At the same time, the role of regional centres as innovation hubs contributing to Finland's competitiveness in the global economy would be strengthened. Public service coordination and efficiency would also be enhanced by reducing fragmentation, especially in areas with potential for economies of scale and scope such as health care and social services. Further areas which would benefit from regional centre steering include education, employment, land-use planning and environmental policies (Ministry of Employment and the Economy, 2012).

In sparsely populated areas, scope for economies of scale is limited. About a fifth of Finland's population lives in rural regions, notably in the north. This is one of the highest shares in the OECD, similar to Denmark and Sweden, although less than Norway (OECD, 2011). Some services, like primary education or basic health care, need to be provided at a reasonable distance from where people live, limiting possibilities of concentration. Even though there might be some trade-off between distance to services and efficiency, as economies of scale in such labour-intensive activities are limited, efficiency gains would likely be offset by transport costs. In more capital-intensive services, such as water supply, economies of scale are larger in production. However, in remote areas, gains in production costs resulting from concentration would be more than offset by higher distribution costs (Fox and Gurley, 2006). Building financially robust municipalities is difficult, as tax bases in remote areas tend to be narrow and isolation increases the cost of providing services. Irrespective of institutional arrangements, remote areas will need to rely heavily on central government subsidies. Whether such subsidies are justified depends on political, strategic and cultural, rather than economic, considerations. In some cases, special arrangements for providing services in remote areas may be appropriate.

Finnish municipalities with more than 40000 inhabitants incur higher costs per capita than those in the 20000-40000 range. Even though this is consistent with the international pattern of a U-shaped relationship, the threshold where costs start rising is low by international standards. This may be surprising, as the wide range of tasks devolved to Finnish municipalities, notably specialised health care and social services should push the optimal size up. However, the threshold above which there might be 
diseconomies of scale is more uncertain than the lower threshold for efficiency and may be more country specific. For example, whereas the international literature points to a threshold of around 250000 inhabitants, diseconomies of scale seem to appear above about 115000 in Japan (Mabuchi, 2001). Furthermore, there were only 25 municipalities with a population of over 40000 in Finland in early 2013, too small a sample to safely draw general conclusions.

Large metropolitan areas, such as the Helsinki region, require strategic planning, which may be best achieved within a single municipality. Sizeable spillovers, as residents use services across the whole metropolitan area rather than those exclusively funded by their municipality, also justify a single government unit. However, municipalities forming a metropolitan area can be very diverse, warranting some local autonomy to meet residents' preferences. Moreover, as noted above, diseconomies of scale tend to appear beyond a certain population size. The experience of mergers of big international cities is mixed. Brisbane has amalgamated a number of entities to create a successful city of 900000 inhabitants, about half the population of the metropolitan area (McKinlay Douglas Limited, 2006). But mergers imposed by provinces have failed to achieve their objectives in Toronto and Montreal, even leading to subsequent "demergers" in the latter case (Box 4). Hence, in metropolitan areas, enhanced cooperation structures may be more appealing than mergers, especially where popular support for the latter is insufficient (OECD, 2003).

The optimal size of municipalities is most often assessed in the literature on the basis of the overall cost of public services per capita. This is, however, a very crude measure of efficiency as numerous reasons may explain differences in spending across municipalities of similar size, including the age and socio-economic structure of the population, density, remoteness, morbidity, financial resources, the quality of public services and the efficiency with which they are delivered. Municipal mergers often aim at increasing the quality of services as much as at reducing costs. However, efficiency improvements are more difficult to measure than costs, explaining at least in part the focus of studies on the latter. Underprovision of complex services, due to technical difficulties or inability to recruit enough qualified personnel may result in lower costs. In smaller cities, expectations of citizens regarding public services may be lower than in bigger ones, leading to lower spending. Insofar as public services are funded through local taxes or user fees, the willingness of residents to pay for services also influences spending. Hence, estimates of optimal size need to be taken with caution. Perhaps more importantly, the optimal size varies with the functions undertaken by local governments.

\section{The optimal size of municipalities varies across functions}

As noted, the U-shaped relationship between size and cost of public services per capita observed at the aggregate level suggests that there is an optimal size for municipalities. However, the optimal size varies across services. More specialised and capital-intensive functions generally imply greater optimal size. According to the international literature, nearly $80 \%$ of municipal tasks are not subject to economies of scale beyond a population of 10000 to 20000 (McKinlay Douglas Limited, 2006; Holzer et al., 2009). However, most Finnish municipalities have a population well below the thresholds where economies of scale in the less complex and capital-intensive functions are considered to be exhausted. For more specialised tasks (e.g. specialised social services) and capital-intensive functions (e.g. utility systems or public works), economies of scale may arise well beyond a population of 20000 . A particular area seldom mentioned in the literature, as it is rarely devolved to municipalities, is specialised health care, where international evidence suggests the optimal catchment area would be around 200000 (OECD, 2012).

\section{Public services can be delivered in different ways}

The issue of the optimal size of a municipality cannot be dissociated from the question of how public services are provided. The relations between scale and efficiency in different types of services suggest that responsibility for more specialised and capital-intensive tasks raises the optimal size of municipalities. This 
is certainly the case if municipalities produce the services they deliver to their residents by themselves. However, services may also be purchased from other producers, either public or private. Purchasing services instead of producing them may reconcile small municipalities with scale efficiency. It may help preserve local accountability and responsiveness, while allowing the production of each type of service on an optimal scale. Public service provision can be separated from production in several ways. Cooperation between municipalities, which is extensive in Finland, is one of them. Public goods and services may also be contracted out through tendering, outsourcing or public-private partnerships.

Cooperation is essential in allowing small Finnish municipalities to deliver the wide range of public services for which they are responsible. The central government, while encouraging voluntary municipal mergers, had until the recent municipal reform proposal consistently presented municipal cooperation as an alternative to mergers for achieving economies of scale and reinforcing the capacity to provide public services. In particular, the project to restructure local government and services (PARAS), launched by the government in 2005, set minimum population targets for a number of activities (e.g. 20000 for primary health care, 50000 for vocational basic education), but left it to municipalities to decide whether these targets should be met through mergers or enhanced cooperation. Municipalities in the Helsinki metropolitan area were required to set up cooperation plans for land use, housing, transportation and services used across municipal boundaries. Cooperation allows economies of scale, but coordination problems across services under the responsibility of different administrative entities may arise. For example, coordination between primary health care managed by municipalities and specialised care run by hospital districts is imperfect (Moisio et al., 2010). Coordination problems have also been reported in other countries, such as Canada and New Zealand (Aulich et al., 2011). Furthermore, special purpose entities are prone to capture by special interests (Slack and Bird, 2012).

\section{Box 5. The Kainuu regional experiment}

A regional government experiment was carried out in Kainuu, a sparsely populated region in Eastern Finland, from 2005 to 2012 . About $60 \%$ of municipal activities, as measured by costs, were transferred to the regional level, including basic health care, social care (except nursery) and secondary education. Municipalities contributed approximately $60 \%$ of their income to the regional administration. The aims were to improve the availability and quality of services, to raise efficiency and to promote regional development. The experiment would also bring some lessons regarding the opportunity of developing an intermediate tier of government across the country.

A study by the Ministry of Finance (Ministry of Finance, 2010) suggests that the experiment might have saved as much as 70 million euros during its first four years. This compares to total spending on health and social services in the region of about 250 million euros in 2009. However, such evaluations need to be taken with caution, if only because the costs that would have been incurred by municipalities in the absence of the experiment are unknown. The study by the Ministry of Finance compared variations in costs in Kainuu to the national average. However, Hämäläinen and Moisio (2012) show that even before the experiment, the evolution of costs in Kainuu and at the national level were very different. To isolate the impact of the experiment, the authors construct a synthetic control region whose differences in cost developments with Kainuu before the experiment were minimal. Using this methodology, they find savings of only about 35 million euros. Furthermore, there are uncertainties about the accuracy of cost data. When data from the Kainuu Regional Council are replaced by data from Statistics Finland, savings become insignificant. Hence, there are serious doubts about the cost savings achieved in Kainuu.

However, the experiment may have brought other benefits, such as improvements in service availability and quality. While the overall results of the experiment are still unclear, the municipalities involved decided at the end of 2011 not to carry on after 2012. The decision was the result of the opposition of only one of the eight municipalities, illustrating the political economy difficulties associated with municipal cooperation.

In many OECD countries, both federal and unitary, a large number of public services are organised by an intermediate level between central government and municipalities (e.g. state, province, region or county), with elected representatives and taxing power. Services managed by the intermediate tier are 
essentially those which benefit from economies of scale, generate spillovers, involve redistribution and are required to meet the same standards across the jurisdiction (Kitchen and Slack, 2006). Intermediate level governments may have an advantage over municipalities in providing public services, notably because they operate on a larger scale and facilitate cooperation and strategic planning. However, they may be less accountable to citizens and more prone to capture by special interest groups. A supplementary tier of administration may also result in less consistent allocation of responsibilities across levels of government, with possible overlaps creating duplication and coordination problems. Finland has experimented with a regional government in the Kainuu region between 2005 and 2012. While the experience may have brought some benefits in service provision, cost savings are uncertain and the experience was stopped, as one municipality refused to carry on (Box 5).

A municipality may purchase services from other public entities or the private sector. A purchaserprovider split introduces market mechanisms in the provision of public services. Municipalities retain the autonomy to make decisions on the supply of services to their residents, within the limits imposed by national regulations. However, services are commissioned to separate providers. A purchaser-provider split may lead to higher efficiency by avoiding conflicts of interest arising when municipalities are both suppliers and producers of public services which employ a large local workforce. For example, some estimates suggest that Finnish municipalities would be willing to accept hospital costs $20 \%$ higher to avoid closing a local hospital (OECD, 2012). Competition between providers may enhance user choice, promote innovation and lower costs where local authorities can commission services from several providers. A split between purchaser and provider is more frequent in utilities than in social services. Nevertheless, one third of Finnish municipalities reported using some kind of purchaser-provider split in health care and social services in 2009 (Tynkkynen et al., 2013). The May 2011 Health Care Act expands user choice in the municipal sector, opening further opportunities for empowering patients and increasing competition between service providers.

However, in a small country like Finland, competition is likely to be limited, although further deregulation of the European Union service market could provide new opportunities in the future. Where competition is weak, contracting out services is unlikely to generate significant cost savings. A number of small Finnish municipalities have commissioned health services from private providers, but this seems to have resulted in higher costs than own provision, reflecting underdeveloped markets and a lack of bargaining power of small municipalities (Mikkola, 2009; Tynkkynen et al., 2013). Some large municipalities like Tampere seem to have been more successful in creating competition and innovation through commissioning private health care providers. Further difficulties with external commissioning include potential lack of contracting expertise in municipalities and challenging quality control. Even so, separating provision from production is worth exploring on a case-by-case basis. Vouchers are increasingly used by municipalities in areas such as elderly care, with apparent success (Kähkönen and Volk, 2008; Moisio et al., 2010). Although vouchers are not suitable for all kinds of services, there seems to be scope to extend their use further, provided stringent evaluation of services ensures that cost reductions are not achieved at the expense of quality.

Finland, like other OECD countries, uses private provision more in technical public services, such as utilities or transport, than in social services, like education or health care (Blöchliger, 2008). On average, about $30 \%$ of public services are delivered by the private sector (Table 2). This is much lower than in Australia, Belgium, the Netherlands and even Denmark, but comparable to Norway and Sweden. Waste collection, most public transport and a significant share of tertiary vocational education are provided by the private sector. A synthetic OECD indicator, which captures dimensions such as contracting out, user choice, competition and user fees, shows significant use of market mechanisms in public service provision in Finland, although notably less than in Australia, Denmark and the Netherlands and slightly less than in Sweden (Figure 12). Public suppliers often enjoy advantages in terms of access to markets, as some services which could potentially be supplied by the private sector are not open to competitive bidding. In 
addition, public entities benefit from tax exemptions and implicit guarantees which lower their financing costs. Moving towards a level playing field between public and private providers would enhance competition and support innovation.

Table 2. Share of public services provided by private providers

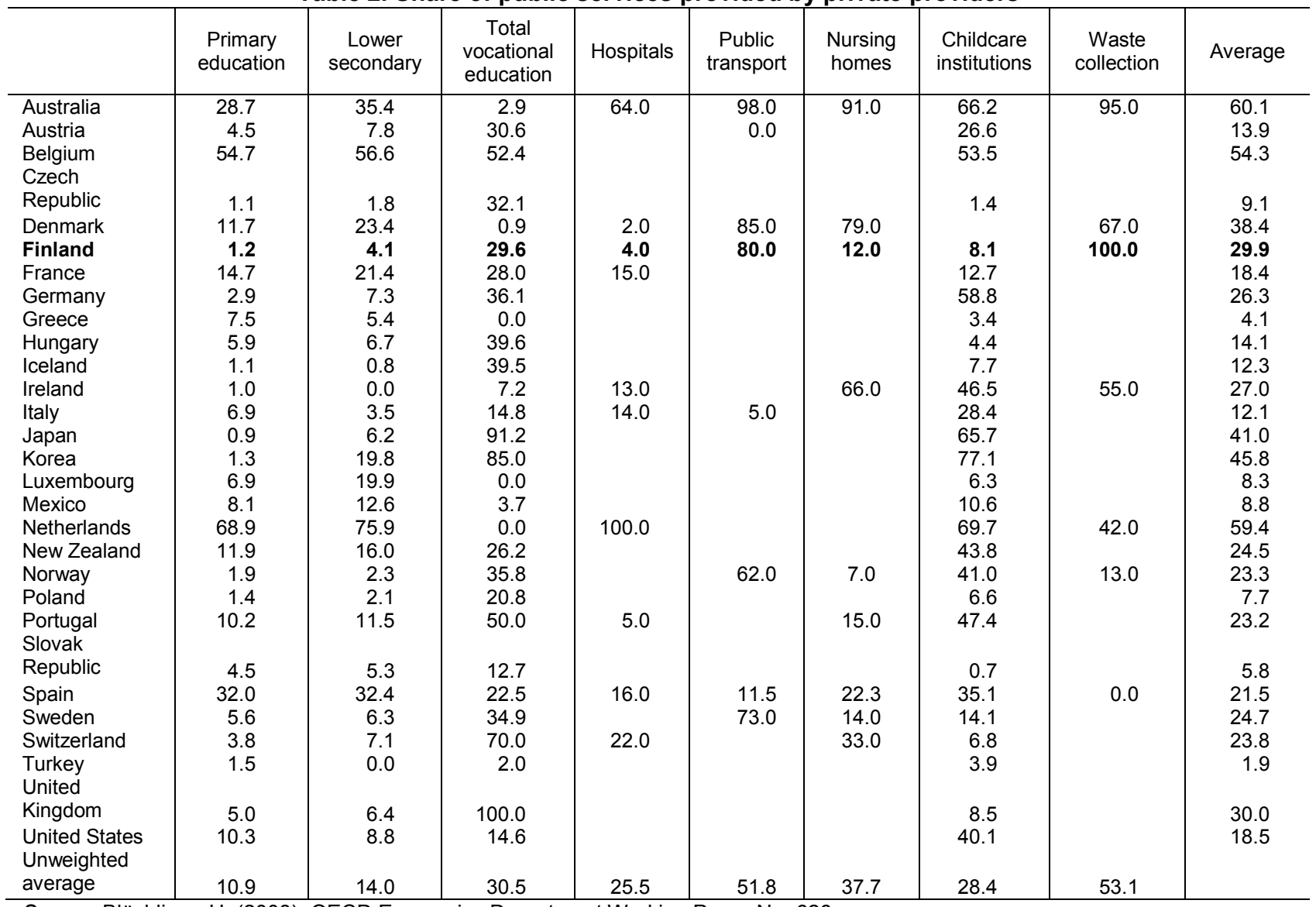

Source: Blöchliger, H. (2008), OECD Economics Department Working Paper No. 626.

Figure 12. Use of market mechanisms in public service provision ${ }^{1}$

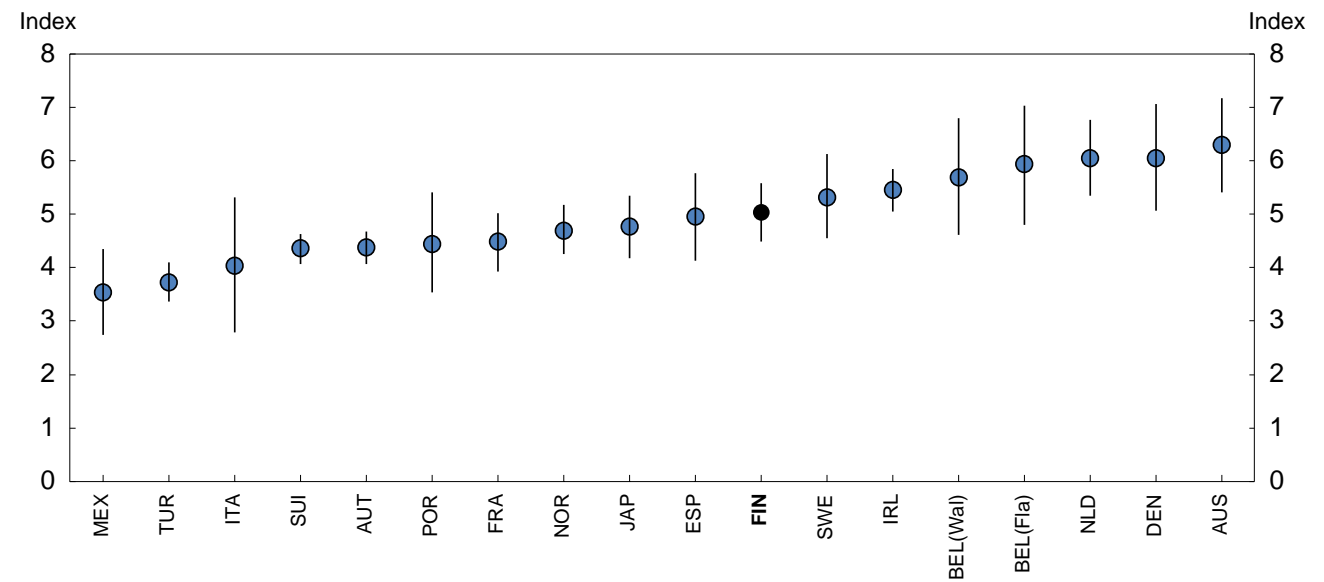

1. Values are normalised to range between 0 and 10 , with a higher value representing more efficient market arrangements in public service provision. The vertical bars denote confidence intervals.

Source: Blöchliger, H. (2008), OECD Economics Department Working Paper No. 626. 
ECO/WKP(2014)17

\section{Larger municipalities would make for greater equity in access to services}

The fragmentation of the provision of public services generates cost inefficiencies, but also inequity in access to services, as small municipalities are often struggling to align service provision with national standards. Residents of economically robust municipalities normally enjoy more even access to services. Within an urban area, mergers will redistribute resources from places with high potential resources to places with limited tax bases. Spillovers within agglomerations justify such redistribution, which also reduces reliance on central government grants. Given the difficulty in capturing local needs through a simple grant formula, this may improve allocation of resources and supply of services. In areas like health care, where municipalities are exposed to exceptional costs, municipal consolidation will improve risk pooling, although the optimal level of pooling would probably be national (OECD, 2012).

\section{Reorganisation of services to achieve efficiency gains}

Economically robust municipalities created through mergers will have the opportunity to improve public services and reap efficiency gains. But it will require substantial reorganisation of public services. The evidence on efficiency gains from recent mergers is mixed (Moisio et al., 2010). Nevertheless, such results need to be taken with caution, as they may be driven by the specific characteristics of municipalities which decided to merge. For example, weaker municipalities may have more incentives to merge than stronger ones, but mergers between weak municipalities may result in limited efficiency gains. Some municipalities have merged after a long period of cooperation and most potential efficiency gains may have been achieved through reorganisation of services prior to the merger. Efficiency gains may also have been hindered by limited reorganisation of services, especially as a transition period of five years, during which public employment is protected, is likely to have delayed restructuring.

There is uncertainty as to whether the voluntary merger process will result in an economically robust municipal sector. Negative initial public reactions to a government proposal to reduce the number of municipalities to about 70 suggest that achieving a critical size may be difficult in many cases. One option would be to impose mergers on municipalities with a population below a certain threshold, as was done recently in Denmark. If this is not possible for political reasons, scaling back responsibilities of smaller municipalities in functions where economies of scale and scope can be achieved could be contemplated. The proposal by the new working group established by the Ministry of Social Affairs and Health sets a minimum of 20000 inhabitants for municipalities to retain control over primary health care and of 50000 to organise specialised care. This would both induce rationalisation in health care provision and improve coordination between primary and specialised care. Adapting the scope of responsibilities of municipalities to their financial and technical capabilities could also be considered in other areas where economies of scale and scope can be achieved. This would encourage mergers and reduce risks of continued inefficiencies and under-provision of services.

\section{Transition costs can be significant}

Transition costs following mergers can be substantial. Hence, when assessing the opportunity of merging municipalities, the potential long-term gains have to be weighed against expected transition costs. The international experience on mergers suggests that transition costs are generally underestimated when merger plans are devised (Aulich et al., 2011). After a merger, it may take time for the new municipality to reach its optimal structure. In particular, rapid adjustment of the number of employees to an optimal level may be hampered by agreements to protect public employment. This is particularly relevant for Finland, where jobs are protected for five years following a merger. The age structure of the Finnish workforce may ease the transition, as many employees are set to retire in the coming years. However, the professional profile of retiring employees will not fully match job reduction requirements. More flexible arrangements than strict job protection for five years could perhaps be devised. It is necessary to be careful not to 
undermine public support for mergers and public employees' motivation to endorse change and improve processes, which would have adverse effects on productivity (De Vries and Sobis, 2013). However, it may be possible to build on Finland's broad social safety nets and effective active labour market policies to engineer a smooth reallocation of labour, in the way it is being done in the case of site closures by private firms. While this would generate costs in the form of severance pay, other benefits, or spending on active labour market policy programmes, it would facilitate the reorganisation of public services, free human resources for the private sector, and enhance the career prospects of public sector workers whose jobs would in any case be at risk after the transition period.

Mergers generally imply equalisation of wages across the merged entities. Since individual pay cuts are unlikely, wages tend to align on the highest levels. Similarly, services provided may converge to the highest standards, which may be desirable and indeed is one of the objectives of the reform, but also induces catch-up costs. Reshaping administrative services will often require investments in information technology systems, which can be costly, especially if municipalities use very different systems before the merger. Nevertheless, developing further the use of information and communication technologies (ICT) offers opportunities to improve cost efficiency and effectiveness of public services. Accordingly, reducing the fragmentation of electronic systems and expanding ICT use at the municipal level are key objectives of the government's structural reform programme (Government of Finland, 2013). Investments may also be necessary to ensure the compatibility of infrastructure networks (Fox and Gurley, 2006). Such costs may be minimal when municipalities have been cooperating closely prior to the merger, but may be significant otherwise. Finally, merging organisations with different cultures is often difficult, as is well known in the corporate world.

Beyond their role in the overall cost-benefit analysis of mergers, transition costs are important to evaluate, because they are likely to influence the merger process itself. High transition costs borne by municipalities may discourage voluntary mergers. Merger grants will transfer part of the burden to the central government, although they are unlikely to cover transition costs fully. The reform awards grants ranging from $€ 2$ million for a merger of two municipalities with combined population below 20000 to $€ 10$ million for a merger of at least six municipalities with combined population above 80000 . High transition costs are likely to dissuade strong municipalities from merging with weaker ones. While in the long term, a larger municipality may prove more prosperous as a result of economies of scale and agglomeration effects, in the short term mergers may look excessively costly because bringing down costs in weaker parts of the new municipalities takes time. Another potential obstacle is existing financial liabilities. The reform of the grant and equalisation system which accompanied the 2007 Danish municipal reform ensured that the latter did not increase overall costs for municipalities (Blöchliger and Vammalle, 2012). This seems to be a prerequisite for success in a voluntary merger process.

\section{Municipal consolidation requires overcoming difficult political obstacles}

Municipal mergers can generate economies of scale and scope, improve the quality of public services and raise efficiency. However, they often face strong opposition from local residents and their representatives, as they are seen as weakening local democracy and accountability and threatening public jobs. Mergers often entail redistribution from more to less affluent municipalities, which can be a further cause of resistance to amalgamation. In many countries, central governments have pushed for voluntary mergers, but forced mergers took place in a number of places. The cost of imposing compulsory mergers could be significant. Self-government is highly valued by citizens. Political voice and governance has been identified as an important determinant of well-being (Stiglitz et al., 2009). Furthermore, the benefits of mergers largely depend on the willingness and ability of municipalities to reorganise services and innovate, and hence may be lost in the event of local resistance. The evidence on performance following voluntary and forced mergers is limited. As mentioned earlier, the merger of municipalities within the Toronto and Montreal metropolitan areas, imposed by provincial governments in spite of strong local opposition, are 
widely seen as failures and were even followed by "de-mergers" in Montreal (Box 4). However, such experiences in large cities may not be very relevant for Finland, except perhaps for the Helsinki metropolitan area. A study on the 1952 Swedish municipal reform finds that municipalities formed voluntarily experienced higher growth than those formed on a compulsory basis, after controlling for other factors (Hanes and Wikström, 2010). While this suggests that voluntary mergers are preferable to forced ones, it should not rule out the latter when no agreement can be reached.

In some cases, imposing mergers is the only way to achieve rapid consolidation. Mergers have been imposed by several Australian states since the 1990s, with apparently limited impact on local democracy, partly because local councils simultaneously took measures to enhance communication with citizens and ensure community engagement. It is sometimes argued that an advantage of compulsory mergers is that they may lead to more rational structures, while voluntary mergers would be determined by agreement possibilities (Aulich et al., 2011). The argument may carry some weight, particularly in the case where strong municipalities are reluctant to merge with weaker ones. The 2007 Danish local government reform gave municipalities strong incentives to enter into voluntary mergers, as those which did not reach the population target could be forced to merge by parliament. Municipalities were also entrusted with new responsibilities transferred from abolished counties. Although municipalities could avoid mergers under certain conditions, this involved renouncing new responsibilities and being forced to enter compulsory agreements to purchase services from neighbouring municipalities. The reform achieved greater consolidation than anticipated. It is often argued that imposing municipal mergers may be difficult in Finland, given its strong tradition of self-government. However, Denmark also has a strong tradition of local democracy and the 2007 reform followed two failed attempts at municipal consolidation (Blöchliger and Vammalle, 2012). Strong leadership from the government and careful design of the reform allowed overcoming obstacles.

The outcome of the municipal reform process in Finland is still uncertain. If large-scale mergers cannot be achieved rapidly, there is a risk that endless debate on administrative structures obscures the final objective of ensuring the provision of high-quality public services in the most efficient way. In that case, municipalities lacking critical size could be encouraged to purchase services for their residents from other public entities or from the private sector, rather than producing them by themselves. Such arrangements do not entail any loss of local choice, as municipalities still decide about the quantity and quality of services provided. Efficient provision of public services is compatible with different administrative structures, but responsibilities and delivery mechanisms need to be adjusted accordingly. 


\section{BIBLIOGRAPHY}

Arnold, J., B. Brys, C. Heady, Å. Johansson, C. Schwellnus and L. Vartia (2011), "Tax Policy for Economic Recovery and Growth”, Economic Journal, Vol. 121, No. 550.

Aulich, C., M. Gibbs, A. Gooding, P. McKinlay, S. Pillora and G. Sansom (2011), "Consolidation in Local Government: A Fresh Look", Australian Centre of Excellence for Local Government, Sydney.

Blöchliger, H., O. Merk, C. Charbit and L. Mizell (2007), "Fiscal Equalisation in OECD Countries", OECD Working Papers on Fiscal Federalism, No. 4, OECD Publishing.

Blöchliger, H. and J. Pinero Campos (2011), “Tax Competition Between Sub-Central Governments”, OECD Economics Department Working Papers, No. 872, OECD Publishing.

Blöchliger, H. and C. Vammalle (2012), Reforming Fiscal Federalism and Local Government: Beyond the Zero-Sum Game, OECD Fiscal Federalism Studies, OECD Publishing.

Blöchliger, H. (2013), "Measuring Decentralisation: The OECD Fiscal Decentralisation Database", in: OECD/Korea Institute of Public Finance (2013), Measuring Fiscal Decentralisation: Concepts and Policies, OECD Fiscal Federalism Studies, OECD Publishing.

Blöchliger, H., B. Égert and K. Bonesmo Fredriksen (2013), "Fiscal Federalism and its Impact on Economic Activity, Public Investment and the Performance of Educational Systems", $O E C D$ Economics Department Working Papers, No. 1051, OECD Publishing.

Borge, L-E and J. Rattsø (2012), "Fiscal Federalism: International Experiences and the Nordic Response", in A. Moisio (ed.): Rethinking Local Government: Essays on Municipal Reform, VATT Publications, No. 61, Government Institute for Economic Research, Helsinki.

De la Maisonneuve, C., C. García, C. André and V. Koen (2014), “The economic consequences of ageing in Finland", OECD Economics Department Working Papers, No. 1120, OECD Publishing.

De Vries, M.S. and I. Sobis (2013), "Consolidation in Local Government: An International Comparison of Arguments and Practices", paper for the $21^{\text {st }}$ NISPAcee Annual Conference "Regionalisation and Inter-regional cooperation", 16-18 May, Belgrade.

Finnish Medical Association (2011), “Finnish Medical Association Study on Physicians' Availability in Health Centres", 5 October.

Fox, W.F. and T. Gurley (2006), "Will Consolidation Improve Sub-National Governments?", The World Bank Policy Research Working Paper, No. 3913.

Fredriksen, K. (2013), "Fiscal Consolidation Across Government Levels - Part 2. Fiscal Rules for Subcentral Governments, Update of the Institutional Indicator", OECD Economics Department Working Papers, No. 1071, OECD Publishing.

Gonand, F., R. Price and I. Joumard (2007), "Public Spending Efficiency: Institutional Indicators in Primary and Secondary Education", OECD Economics Department Working Papers, No. 543, OECD Publishing.

Government of Finland (2013), Government Decision on Implementing the Structural Policy Programme, 29 November. 
Hämäläinen, K. and A. Moisio (2012), "One or Two Tiers of Local Government? - The Cost Effects of Regional Experiment”, Government Institute for Economic Research, Helsinki.

Hanes, N. and M. Wikström (2010), “Amalgamation Impacts on Local Growth: Are Voluntary Municipal Amalgamations More Efficient than Compulsory Amalgamations?", Canadian Journal of Regional Science, Vol. 33, No. 1.

Holzer, M., J. Fry, E. Charbonneau, G. Van Ryzin, T. Wang and E. Burnash (2009), "Literature Review and Analysis Related to Optimal Municipal Size and Efficiency", Local Unit Alignment, Reorganization, and Consolidation Commission, New Jersey.

Jolkkonen, A., P. Koistinen and A. Kurvinen (2012), "Reemployment of Displaced Workers - The Case of a Plant Closing on a Remote Region in Finland", Nordic Journal of Working Life Studies, Vol. 2, No. 1.

Kähkönen, L. and R. Volk (2008), "Kuntien vanhuspalvelujen kilpailuttamiskokemuksia” ("Experiences from Competitive Tendering in Elderly Care"), Kunnallisalan Kehittämissäätiö Kunnat ja Kilpailu publications 4, Helsinki (in Finnish).

Kitchen, H. and E. Slack (2006), "Providing Public Services in Remote Areas", in R. Bird and F. Vaillancourt (eds), Perspectives on Fiscal Federalism, World Bank Institute, Washington, DC.

Kröger, T. (2011), "Retuning the Nordic Welfare Municipality - Central Regulation of Social Care Under Change in Finland", International Journal of Sociology and Social Policy, Vol. 31, No. 3/4.

Mabuchi, M. (2001), "Municipal Amalgamation in Japan”, World Bank Institute Working Paper, Washington. DC.

McKinlay Douglas Limited (2006), "Local Government Structure and Efficiency", report prepared for Local Government New Zealand.

McLean, C., G. Paget and B. Walisser (2006), "Local Government Excellence Through Collaborative Partnerships", paper prepared for the World Urban Forum III, June 19-23, Vancouver, B.C., Ministry of Community Services, Victoria, British Columbia.

Mikkola, H. (2009), “Toimiiko kilpailu lääkäripalveluissa?” (“Does Competition Work in Medical Services?"), Kunnallisalan Kehittämissäätiö Kunnat ja Kilpailu, publication No. 15, Helsinki (in Finnish).

Ministry of Employment and the Economy (2012), Finland's National Regional Development Targets for 2011-2015. An Economically, Socially and Environmentally Sustainable Finland, Publications of the Ministry of Employment and the Economy, Regional development, 6/2012.

Ministry of Finance (2010), Proposals by the follow-up group for the Kainuu self-government trial (in Finnish or in Swedish), Ministry of Finance, 27/2010, Helsinki.

Ministry of Finance (2013), Economic Survey, Spring 2013, Helsinki.

Moisio, A. (2002), "Determinants of Expenditure Variation in Finnish Municipalities", VATT Discussion papers, No. 269, Government Institute for Economic Research, Helsinki.

Moisio, A., H.A. Loikkanen and L. Oulasvirta (2010), "Public Services at the Local Level - The Finnish Way", VATT Policy Reports 2/2010, Government Institute for Economic Research, Helsinki. 
Moisio, A. (ed.) (2012) Rethinking Local Government: Essays on Municipal Reform, VATT Publications, No. 61, Government Institute for Economic Research, Helsinki.

Muellbauer, J. (2006), "Housing and Personal Wealth in a Global Context", paper prepared for the United

Nations-WIDER Project Meeting, "Personal Assets from a Global Perspective", Helsinki, Finland, 4-6 May.

OECD (2003), OECD Territorial Reviews - Helsinki, Finland, OECD publishing.

OECD (2011), OECD Regions at a Glance 2011, OECD Publishing.

OECD (2012), OECD Economic Surveys: Finland, OECD publishing.

OECD (2013), "Draft OECD Recommendation on Principles for Effective Public Investment, A Shared Responsibility Across Levels of Government", Version for public comment, July.

OECD (forthcoming), Financing Investment for Growth in a Tight Fiscal environment: A Sub-National Perspective.

Paris, V., M. Devaux and L. Wei (2010), "Health Systems Institutional Characteristics: A Survey of 29 OECD Countries", OECD Health Working Papers, No. 50, OECD Publishing.

Prime Minister's Office (2011), "Programme of the Finnish Government”, Helsinki.

Slack, E. and R. M. Bird, “Merging Municipalities: Is Bigger Better?”, in Moisio, A. (ed.): Rethinking Local Government: Essays on Municipal Reform, VATT Publications, No. 61, Government Institute for Economic Research, Helsinki.

Smith, D. (2007), "Inter-municipal Collaboration Through Forced Amalgamation: A Summary of Recent Experiences in Toronto \& Montreal", paper prepared for the Project on New Public Consortia for Metropolitan Governance (NPC Project), Vancouver, 14-19 October.

Stiglitz, J., A. Sen and J.-P. Fitoussi (2009), Report by the Commission on the Measurement of Economic Performance and Social Progress, www.stiglitz-sen-fitoussi.fr/documents/rapport_anglais.pdf.

Sutherland, D., R. Price and I. Joumard (2005), "Sub-Central Government Fiscal Rules", OECD Economic Studies, No. 41, 2005/2.

Ter-Minassian, T. (2007), "Fiscal Rules for Subnational Governments: Can They Promote Fiscal Discipline?", OECD Journal on Budgeting, Vol. 6, No. 3.

Tiebout, C.M. (1956), “A Pure Theory of Local Expenditures”, Journal of Political Economy, Vol. 64, No. 5.

Tynkkynen, L.K., I. Keskimäki and J. Lehto (2013), "Purchaser-Provider Splits in Health Care - The Case of Finland", Health Policy, Vol. 111, Issue 3.

Vuorenkoski L., P. Mladovsky and E. Mossialos (2008), Finland: Health System Review, Health Systems in Transition.Vol. 10, No. 4, European Observatory on Health Systems and Policies. 


\section{WORKING PAPERS}

The full series of Economics Department Working Papers can be consulted at www.oecd.org/eco/workingpapers

1120. The economic consequences of ageing: the case of Finland (June 2014) by Christine de la Maisonneuve, Christophe André, Clara Garcia and Vincent Koen

1119. Making the most of skills in Denmark

(June 2014) by Stéphanie Jamet and Vincent Koen

1118. Trade specialisation and policies to foster competition and innovation in Denmark (June 2014) by Müge Adalet McGowan

1117. Policies for making the Chilean labour market more inclusive (June 2014) by Aida Caldera Sanchez

1116. Spillover effects from exiting highly expansionary monetary policies

(May 2014) by Łukasz Rawdanowicz, Romain Bouis, Jérôme Brezillon, Ane Kathrine Christensen and Kei-Ichiro Inaba

1115. Economic policies and microeconomic stability: a literature review and some empirics (April 2014) by Paula Garda and Volker Ziemann

1114. How to improve Israel's health-care system (April 2014) by Philip Hemmings

1113. How to improve taxes and transfers in Israel (April 2014) by Philip Hemmings

1112. New evidence on the determinants of industrial specialisation (April 2014) by Asa Johansson and Eduardo Olaberria

1111. Economic growth from the household perspective: GDP and income distribution developments across OECD countries

(April 2014) by Orsetta Causa, Sonia Araujo, Agnès Cavaciuti, Nicolas Ruiz and Zuzana Smidova

1110. Would a growth slowdown in emerging markets spill over to high-income countries? A quantitative assessment (April 2014) By Patrice Ollivaud, Elena Rusticelli and Cyrille Schwellnus

1109. Short-term indicator models for quarterly GDP growth in the BRIICS: A small-scale bridge model approach

(April 2014) by Thomas Chalaux and Cyrille Schwellnus

1108. The prudential regulation of financial institutions: why regulatory responses to the crisis might not prove sufficient

(March 2014) by William R. White

1107. OECD forecasts during and after the financial crisis: a post mortem 
(March 2014) by Nigel Pain, Christine Lewis, Thai-Thanh Dang, Yosuke Jin and Pete Richardson

1106. Fairly sharing the social impact of the crisis in Greece

(January 2014) by Vassiliki Koutsogeorgopoulou, Manos Matsaganis, Chrysa Leventi and Jan-David Schneider

1105. Dividing the pie in Brazil: income distribution, social policies and the new middle class (January 2014) by Jens M. Arnold and João Jalles

1104. New indicators of competition law and policy in 2013 for OECD and non-OECD countries (December 2013) by Enrico Alemani, Caroline Klein, Isabell Koske, Cristiana Vitale and Isabelle Wanner

1103. The effect of government debt, external debt and their interaction on OECD interest rates (December 2013) by David Turner and Francesca Spinelli

1102. The state of the banking sector in Europe (December 2013) by Dirk Schoenmaker and Toon Peek

1101. Getting Irish youth on the job track

(December 2013) by Alberto González Pandiella

1100. New econometric estimates of long-term growth effects of different areas of public spending (December 2013) by Omar Barbiero and Boris Cournède

1099. Cross-country spillovers from fiscal consolidations

(December 2013) by Antoine Goujard

1098. Informal employment in Russia: definitions, incidence, determinants and labour market segmentation

(December 2013) by Hartmut Lehmann and Anzelika Zaiceva

1097. Capacity needs in the automobile industry in the short- to medium run

(November 2013) by Caroline Klein and Isabell Koske

1096. Environmental policies and productivity growth - a critical review of empirical findings

(November 2013) by Tomasz Koźluk and Vera Zipperer

1095. Green growth challenges and the need for an energy reform in Mexico

(November 2013) by Carla Valdivia de Richter

1094. From bricks to brains: increasing the contribution of knowledge-based capital to growth in Ireland

(November 2013) by David Haugh

1093. China's march to prosperity: reforms to avoid the middle-income trap

(November 2013) by Vincent Koen, Richard Herd and Sam Hill

1092. Multi factor productivity with natural capital

(November 2013) by Nicola Brandt, Paul Schreyer and Vera Zipperer 